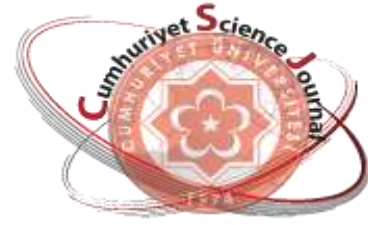

e-ISSN: $2587-246 X$

ISSN: $2587-2680$

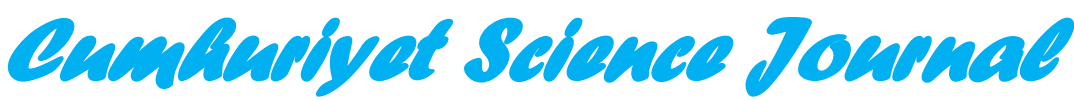

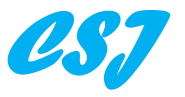

Cumhuriyet Sci. J., Vol.38-4, Supplement (2017) 138-155

\title{
A Computational Study of 1-Substituted Methyl 9-Methyl-9H-Pyrido[3,4- $b$ ]indole-3-Carboxylate: Quantum Chemical Descriptors, FMO and NBO
} Analysis

\author{
Mustafa ELIK*, Goncagul SERDAROGLU \\ Department of Mathematics and Science Education, Cumhuriyet University, Sivas / TURKEY
}

Received: 19.11.2017; Accepted: 06.12.2017

http://dx.doi.org/10.17776/csj.356185

\begin{abstract}
This work dealt with the investigation of the methyl 9H-pyrido[3,4-b]indole-3-carboxylate (Basic compound) and its $\mathrm{C} 1$-substituted derivatives to search for the best substituent group that enhances the chemical reactivity behavior of the Basic compound. In this context, DFT (Density Functional Theory) calculations were performed at B3LYP level of theory at three basis sets, also in 10 different solvents because the chemical behavior strongly depends on the solvent media. This study revealed that the anthracene-9-yl substitution on the $\mathrm{C} 1$-position of the Basic compound has increased the chemical reactivity of the Basic compound more than those of the other substituent groups. Also, the results were supported by the NBO analysis: the highest electron delocalization for the structure A was found out $\pi \mathrm{C} 19-\mathrm{C} 20 \rightarrow \mathrm{p}_{\mathrm{v}} \mathrm{C} 42-\mathrm{C} 43$ with the interaction energy of the 50.98 kcalmol-1, due to the anthracene-9-yl substitution on the C1-position of the Basic compound makes the electron delocalization on the substituted compound enhances, at $6-311++\mathrm{g} * *$ basis set in the water phase.
\end{abstract}

Keywords: Quantum chemical descriptors, substituent effect, NBO, FMO analysis

1- Sübstitüeli Metal-9-Metil-9H-Pirido [3,4-b]indol-3-Karboksilat Üzerine

Hesaplamalı Kimya Çalışması: Kuantum Kimyasal Belirleyiciler, FMO ve NBO Analizi

\begin{abstract}
Özet: Bu çalışma metil 9H-pirido [3,4-b] indol-3-karboksilat (Temel bileşik) ve bu bileşiğin C1-substitüeli türevlerinin incelenmesi ile Temel bileşiğin kimyasal tepkime davranışını arttıran en iyi substitüe grubu belirlemek ile ilgilenmiştir. Bu bağlamda DFT (Yoğunluk Fonksiyonel Teori) hesaplamaları 3 temel set ve kimyasal aktivite davranışı çözücü ortamına bağlı olduğundan dolayı 10 farklı çözücü ortamında yapılmıştır. $\mathrm{Bu}$ çalışma, Temel bileşiğin C1-konumundaki antrasen-9-il substitüe grubunun, diğer sübstitüe gruplarınınkinden daha fazla Temel bileşiğin kimyasal reaktivitesini arttırdığını ortaya koymuştur. Ayrıca, sonuçlar NBO analizi ile desteklenmiştir: $6-311++\mathrm{g}(\mathrm{d}, \mathrm{p})$ temel seti ile su fazında, Temel bileşiğin C1 konumunda antrasen-9-il substitüe grubu bulunduğunda elektron delokalizasyonu arttı̆̆ından dolayı, A bileşiğinin en büyük elektron delokalizasyonu $\pi \mathrm{C} 19-\mathrm{C} 20 \rightarrow \mathrm{p}_{\mathrm{v}} \mathrm{C} 42-\mathrm{C} 43$ elektronik geçişi için $50.98 \mathrm{kcalmol}^{-1}$ olarak bulunmuştur.
\end{abstract}

Anahtar Kelimeler: Kuantum kimyasal tanımlayıcılar, bağlı grup etkisi, NBO, FMO analizi

* Corresponding author. Email address: melik@cumhuriyet.edu.tr

http://dergipark.gov.tr/csj $\quad$ (C)2016 Faculty of Science, Cumhuriyet University 


\section{INTRODUCTION}

Beta Carboline $(\beta C)$ with the structural unit (9hydro-pyrido $(3,4-b)$ indole) is a prototype molecule being the planar polycyclic system and its derivatives are natural-occurring in many medicinal plants as well as are produced from the marine organism and the human tissues as secondary metabolism. [1-3] Because of their polycyclic structure, they act on different receptor sites such as Benzodiazepine Receptor (BzR), imidazoline and serotonin receptors in CNS (Central Nervous System) [4-6], and therefore they have invaluable importance in terms of the pharmaceutical.

In the literature, there is much research of $\beta C$ and of its derivatives about their actions on several receptor sites and/or about their biochemical/biophysical properties which is important to illuminate the causes of the challenging diseases, like cancer and AIDS. Because of the anticancer and anti-HIV activities, novel $\beta C$ derivatives are synthesized and continue to be increasingly synthesized. [7-10] Also, the cytotoxicity is important to be determining the good anti-cancer agents as well as for investigating the drug/agent used in the many other diseases. For this reason, the scientists have led to study the cytotoxic activity of the $\beta C$ s. [11-13] In the past, it had been suggested by Cao R. et al. that the type of the substituent group and its location on the $\beta C$ nucleus, especially the position 1- and position 9-, are very important to improve the cytotoxic potency of the $\beta$ Cs. [11] Also, Chen Z. and coworkers have synthesized the novel $\beta C$ derivatives as the potent antitumor agents to determine the structural requirements of them and to evaluate the structure-activity relationship. They have shown that the cytotoxic potency of each derivative depends on both the length of the substituent group as well as the position of the substituent group of $\beta C$ s. [13] On the other hand, the photochemical/ photophysical properties [14-17] of the $\beta C$ s have also commonly investigated by scientist because the cytotoxic activity is affected by light. Until now, the acid-base equilibria of the $\beta C$ s have been widely studied due to it is vital to elucidate the photo tautomerism and $\mathrm{H}$-bonding interaction affecting the photochemical/photophysical properties of the $\beta C$ s. Reyman and co-workers [18] have suggested that the proton-transfer reactions strongly depends on the solvent-compound and on the solvent-cage interaction resulting in the change of the fluorescence Dynamics due to the increase in the charge density of pyridine nitrogen (the stronger base) in the ground state, and vice versa for pyrrole nitrogen (stronger acid). In another work, Biondic MC and Erra-Balsells R [19] had determined the $\mathrm{pKa}$ of the $\beta C$ derivatives by spectrophotometric methods to evaluate the acidbase equilibrium in the ground and in the excited states of the $\beta \mathrm{Cs}$; they had proposed that the partially hydrogenated $\beta C$ s were more basicity than the full aromatic pyridinic ring. Guan $\mathrm{H}$ and et al. [20] had also synthesized the novel 1,3,9trisubstituted $\beta \mathrm{Cs}$ derivatives as the photosensitizers. Accordingly, they had confirmed that the nitrogen atom in position-2 could contribute to the photophysical properties of the compound more than the alkyl or aryl group in position -9 .

Although these compounds have been extensively studied on from their synthesis to the photochemical properties of them, the physical and chemical reasons of underlying their current effects have not been adequately illuminated. Nowadays the computational tools have got increasingly used to explain the mechanism of action of the pharmaceutical important compounds, but the current computational works are limited [4-5, 17, 21-22], and even Molecular Orbital calculations for the Basic compound have not been found in the literature. The only computational study was performed to explain the photophysical properties of the Basic compound. [22]

Mainly, this work aims to determine the comprehensive the quantum chemical parameters of studied molecules how substituent group influenced the efficiency of the Basic structure, not only in the gas-phase but in the 10 solvents as well. The first, the solvation free energy and the dipole moments of the studied molecules were calculated to determine the chemical stability behavior of the 
studied compounds. Second, Natural Bond Orbital (NBO) analysis was carried out to determine the possible intramolecular interactions such as the hyperconjugation, resonance, electron delocalization resulting in the chemical stability of the compounds. After that, the Frontier Molecular Orbital (FMO) analysis was performed to show the nucleophilic or electrophilic attack centers. Last, the quantum chemistry parameters such as electrophilicity, the capability of charge transfer, electronic chemical potential, the Energy Gap obtained from HOMO and LUMO energies were calculated to determine which substituent group influenced the efficiency of the Basic structure.

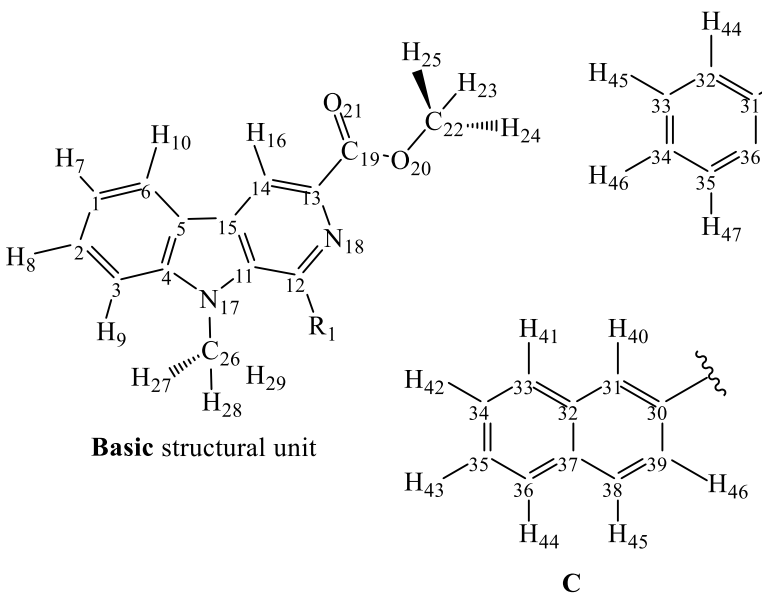

C

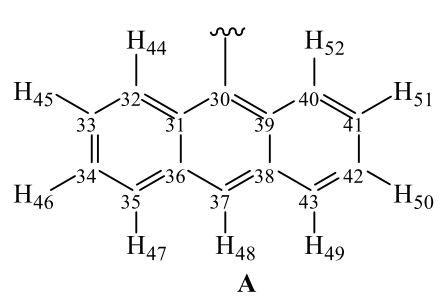

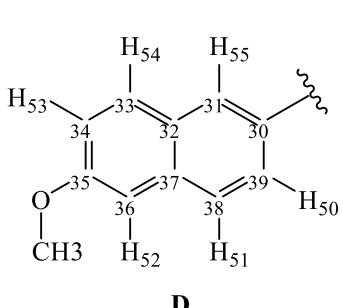

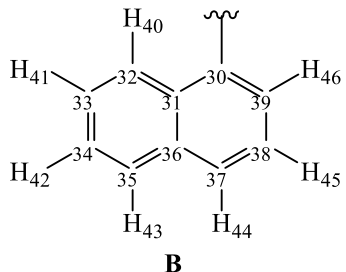

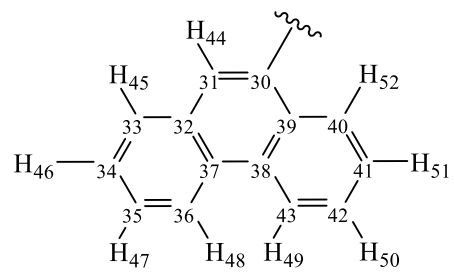

$\mathbf{E}$

Figure 1. The methyl 9H-pyrido[3,4-b]indole-3-carboxylate (Basic compound) and its substituent groups as A (anthracen-9-yl), B (naphthalene-1-yl), C (naphthalene-2-yl), D (6-methoxynaphthalene-2-yl), E (phenanthrene-9-yl).

\section{COMPUTATIONAL METHOD}

In this study, the methyl 9H-pyrido[3,4-b]indole3-carboxylate (Basic) and its derivatives depicted in Figure 1 were optimized at $6-31 \mathrm{G}(\mathrm{d}, \mathrm{p})$ basis set in the gas phase. In this study, all methyl $9 \mathrm{H}-$ pyrido[3,4-b]indole-3-carboxylate derivatives depicted in Figure 1 were optimized at $6-31 \mathrm{G}(\mathrm{d}, \mathrm{p})$ basis set in the gas phase. Then the stable structures in the gas phase were used as a starting structure in the 10 solvents media to look for the dielectric media effect on both the quantum chemical and physicochemical parameters. The same calculation routes were repeated at both the $6-311++G(d, p)$ and $6-31+G(d, p)$ basis sets to investigate the basis set effect on the chemical reactivity behavior of these compounds. The Gaussian 09W [23] software package was used for all DFT calculations at B3LYP level of theory which is a combination of Becke's three-parameter hybrid exchange functional [24] and the Lee-YangParr correlation functional. [25] The solvent phase calculations have been employed with IPCM (Polarized Continuum Model (PCM) with
Isodensity version) [26- 27] in the 10 solvent environments with $\varepsilon=2.37,4.71,5.70,8.93,9.16$, $24.85,32.61,36.69,46.83,78.36$ to simulate Toluene (T), $\mathrm{CHCl}_{3}$ (Chloroform, C), $\mathrm{C}_{6} \mathrm{H}_{5} \mathrm{Cl}$ (Chlorobenzene, $\mathrm{CB}$ ), $\mathrm{CH}_{2} \mathrm{Cl}_{2}$ (Dichloromethane, DCM), Quinoline (Q), $\mathrm{C}_{2} \mathrm{H}_{5} \mathrm{OH}$ (ethanol, E), $\mathrm{CH}_{3} \mathrm{OH}$ (Methanol, M), Acetonitrile (A), DMSO (dimethylsulfoxide, DMSO), $\mathrm{H}_{2} \mathrm{O}$ (water), respectively.

In according to Koopmans Theorem [28], the Ionization energy (I) and electron affinity (A) can be expressed through HOMO and LUMO orbital energies [29] as follow:
$\mathrm{I}=-\mathrm{E}_{\mathrm{HOMO}}$

$$
\mathrm{A}=-\mathrm{E}_{\mathrm{LUMO}}
$$

DFT based global descriptors such as electronic chemical potential $(\mu)$, global hardness $(\eta)$, electrophilicity $(\omega)$ and the maximum charge transfer index ( $\triangle$ Nmax) have been represented by Parr R.G. and co-workers [30] as follow:

$\mu=-\frac{I+A}{2} \quad$ (3) $\quad \eta=\frac{I-A}{2}$ 
$\omega=\frac{\mu^{2}}{2 \eta}$

$$
\Delta N_{\max }=\frac{I+A}{2(I-A)}
$$

\section{RESULTS AND DISCUSSION}

\section{1. Molecular Geometry}

Table 1 has shown the selected structural parameters of each studied compounds at B3LYP/6-311++G** level of theory in the water phase. Full optimized parameters of these molecules are given as supporting information of this article (Table S1). There are no important differences between the results obtained from the different solvent media even though they are not the same value. From Table 1, the bond lengths of C11- C15 for the Basic molecule and it substituted derivatives have changed in the range of $1.4 \AA-1.5$ $\AA$. The biggest changing in the bond lengths with adding the substituent group to the Basic structure is calculated for the bond length of C12-H30 (R1), that is, this bond length is calculated as $1.1 \AA$ for Basic compound and as $1.5 \AA$ for $\mathbf{A}$. It is clear from Table 1 that the bond lengths for each substituted derivative were calculated as bigger than that of the Basic compound. If it is looked at the results of the valence angles, there is no significant difference between the Basic compounds' valence angles and those of its derivatives except the N17-C4-C3 bond angle. The N17-C4-C3 bond angle is determined as $109.4^{0}$ for the Basic structure but this valence angle is about the $129.2{ }^{\circ}$ for the structure $\mathbf{E}$. The N17-C4-C3 bond angle for $\mathbf{E}$ has distorted with the phenanthrene-9-yl substituent group attached to the Basic structure. One of the important things what we should express here is that there is no experimental data about structural parameters of the substituted Basic compound in literature. As upon our best acknowledge, there are the bond angles of the 3-carboxylic acid-1,2,3,4terahydroharmane which is closely related to the derivatives studied in this work and we have compared the structural parameters of the 1substituted Basic compound with those of this compound. Accordingly, the valence angles of C6C5-C15, C6-C5-C4, C15-C5-C4, N17-C4-C5, C11-N17-C4 for the 3-carboxylic acid-1,2,3,4terahydroharmane were determined as $134.7^{\circ}$, $119.5^{0}, 105.7^{0}, 108.7^{0}, 107.6^{0}$ by Codding P.W, in the past. [31] In this work, the same valence angles for the structure $\mathbf{A}$ is found to be $133.9^{0}, 120.0^{0}$, $106.0^{0}, 109.6^{0}, 108.5^{0}$ by B3LYP/6-311++G(d, p) level of the theory in the aqueous phase, respectively. Here the biggest distortion corresponding to the Basic molecule is found to be the N18-C13-C19-O20 dihedral angle for the compound $\mathbf{D}$ with $2^{0}$ even though there is no big change of this angle. Notwithstanding, the N18C12-C36-C39 dihedral angle of each substituted structure is quite different from each other. For example, this dihedral angle for the structure $\mathbf{A}$ is $82.9^{0}$, so it can be said that the substituent part (anthracen-9-yl) of the $\mathbf{A}$ is nearly perpendicular to the planar indole ring with $\sim 7^{0}$ deviation angle. But for the structure D including the 6methoxynaphthalene-2-yl group substitution at C1position of the Basic structure, the N18-C12-C36C39 dihedral angle is $-47.8^{0}$. Moreover, the same dihedral angle for the structure $\mathbf{C}$ containing the naphthalene-2-yl group substitution at C1-position of the Basic structure is at $-48.6^{0}$. so, it seems that the methoxy group at 6- position of the substituent part of the structure D doesn't affect the N18-C12C36-C39 dihedral angle because this angle is calculated very similar to each other for structures C and D. The N18-C13-C19-O20 torsion angle for Basic compound is determined as $0^{0}$ by Dorey G. et al. [32] and it has been computed as $-180^{\circ}$ in this work. For the other substituted structures, $\mathbf{A}, \mathbf{B}, \mathbf{C}$, $\mathbf{D}$ and $\mathbf{E}$, the N18-C13-C19-O20 torsion angle is close to the 00 which means that the $\mathrm{C}=\mathrm{O}$ group at $\mathrm{C} 3$-position are on the same plane as indole ring. 
Table 1. The selected geometric parameters for the structures A-E calculated at B3LYP/6-311++G(d,p) basis set in the water phase.

\begin{tabular}{|c|c|c|c|c|c|c|}
\hline Bond Length $(\AA)$ & Basic & $\mathbf{A}$ & $\mathbf{B}$ & $\mathbf{C}$ & D & $\mathbf{E}$ \\
\hline N17-C26 & 1.5 & 1.5 & 1.5 & 1.5 & 1.5 & 1.5 \\
\hline N17-C11 & 1.4 & 1.4 & 1.4 & 1.4 & 1.4 & 1.4 \\
\hline N17-C4 & 1.4 & 1.4 & 1.4 & 1.4 & 1.4 & 1.4 \\
\hline C11-C15 & 1.4 & 1.4 & 1.4 & 1.4 & 1.4 & 1.4 \\
\hline C11-C12 & 1.4 & 1.4 & 1.4 & 1.4 & 1.4 & 1.4 \\
\hline N18-C12 & 1.3 & 1.3 & 1.3 & 1.3 & 1.3 & 1.3 \\
\hline $\mathrm{N} 18-\mathrm{C} 13$ & 1.4 & 1.3 & 1.3 & 1.3 & 1.3 & 1.3 \\
\hline C13-C19 & 1.5 & 1.5 & 1.5 & 1.5 & 1.5 & 1.5 \\
\hline $\mathrm{C} 19-\mathrm{O} 20$ & 1.3 & 1.3 & 1.3 & 1.3 & 1.3 & 1.3 \\
\hline C19-O21 & 1.2 & 1.2 & 1.2 & 1.2 & 1.2 & 1.2 \\
\hline $\mathrm{C} 22-\mathrm{O} 20$ & 1.4 & 1.4 & 1.4 & 1.4 & 1.4 & 1.4 \\
\hline C12-H30 (R1) & 1.1 & 1.5 & 1.5 & 1.5 & 1.5 & 1.5 \\
\hline \multicolumn{7}{|l|}{ Valence angle $\left({ }^{0}\right)$} \\
\hline N17-C26-H29 & 109.6 & 109.2 & 109.0 & 111.7 & 111.7 & 110.1 \\
\hline N17-C11-C12 & 130.8 & 132.3 & 132.2 & 132.2 & 132.2 & 132.0 \\
\hline N17-C4-C3 & 109.4 & 128.9 & 129.0 & 129.1 & 129.1 & 129.2 \\
\hline C11-C15-C5 & 106.5 & 107.1 & 107.1 & 107.1 & 107.1 & 107.0 \\
\hline C11-C12-N18 & 121.3 & 120.1 & 120.0 & 119.8 & 119.7 & 120.1 \\
\hline N18-C12-H30 (R1) & 117.0 & 115.4 & 115.6 & 115.4 & 115.5 & 115.9 \\
\hline N18-C13-C14 & 123.6 & 123.2 & 123.3 & 123.2 & 123.3 & 123.3 \\
\hline N18-C13-C19 & 118.5 & 118.6 & 118.6 & 118.6 & 118.7 & 118.6 \\
\hline C13-C19-O20 & 113.6 & 113.6 & 113.6 & 113.6 & 113.6 & 113.6 \\
\hline C13-C19-O21 & 123.4 & 123.3 & 123.3 & 123.3 & 123.3 & 123.3 \\
\hline C19-O20-C22 & 116.3 & 116.3 & 116.3 & 116.4 & 116.4 & 116.3 \\
\hline O20-C19-O21 & 123.0 & 123.1 & 123.1 & 123.1 & 123.1 & 123.1 \\
\hline $\mathrm{H} 25-\mathrm{C} 22-\mathrm{O} 20$ & 110.4 & 110.4 & 110.4 & 110.4 & 110.4 & 110.4 \\
\hline $\mathrm{C} 3-\mathrm{C} 4-\mathrm{C} 5$ & 121.5 & 121.5 & 121.4 & 121.3 & 121.3 & 121.2 \\
\hline C12-C36-C39 & & 119.8 & 119.2 & 119.4 & 119.5 & 120.9 \\
\hline C12-C36-C32 & & 119.6 & 121.0 & 121.4 & 121.5 & 119.2 \\
\hline \multicolumn{7}{|l|}{ Dihedral angle $\left({ }^{0}\right)$} \\
\hline C4-N17-C26-H29 & -42.2 & -45.5 & -40.5 & -92.7 & -92.3 & -146.8 \\
\hline C11-N17-C26-H29 & 141.8 & 137.0 & 139.1 & 94.3 & 95.2 & 33.9 \\
\hline N17-C11-C12-N18 & -179.4 & -179.4 & -177.9 & 174.0 & 173.8 & -177.8 \\
\hline C26-N17-C4-C3 & 2.5 & 1.1 & -1.2 & 6.6 & 7.1 & -179.0 \\
\hline N17-C11-C15-C5 & -0.7 & -0.6 & -1.1 & 2.1 & 2.2 & -1.3 \\
\hline C13-N18-C12-H30 (R1) & 179.6 & 179.3 & 179.0 & -175.4 & -175.3 & 177.0 \\
\hline C12-N18-C13-C14 & -0.2 & -0.3 & -0.7 & 1.0 & 1.2 & -0.5 \\
\hline C12-N18-C13-C19 & 179.9 & 179.9 & 179.8 & -179.9 & -179.7 & -179.9 \\
\hline N18-C13-C19-O20 & -180.0 & -0.1 & -1.0 & 1.7 & 2.0 & -0.3 \\
\hline N18-C13-C19-O21 & 0.0 & 179.9 & 179.1 & -178.5 & -178.3 & 179.7 \\
\hline C13-C19-O20-C22 & -179.9 & -179.9 & -179.9 & -179.2 & 179.9 & -179.9 \\
\hline $\mathrm{O} 20-\mathrm{C} 19-\mathrm{C} 13-\mathrm{C} 14$ & -179.9 & -179.9 & 179.5 & -179.2 & -178.9 & -179.8 \\
\hline $\mathrm{H} 25-\mathrm{C} 22-\mathrm{O} 20-\mathrm{C} 19$ & 60.7 & 60.7 & 60.6 & 60.8 & 60.9 & 60.6 \\
\hline N18-C13-C14-H16 & -179.7 & -179.6 & -179.0 & 178.1 & 178.0 & -179.1 \\
\hline C3-C4-C5-C6 & 0.5 & 0.4 & 0.3 & -0.2 & -0.2 & 0.5 \\
\hline N18-C12-C36-C39 & & 82.9 & 69.9 & -48.6 & -47.8 & 78.7 \\
\hline N18-C12-C36-C32 & & -95.7 & -108.0 & 127.5 & 128.0 & -100.0 \\
\hline
\end{tabular}


Table 2. The Solvation Free Energy (in kcalmol ${ }^{-1}$ ) of both the Basic compound and its C1- substituted derivatives, in 10 solvent environments with 6-31g(d,p), 6-31+g(d,p) and 6-311++g(d,p) basis sets.

\begin{tabular}{|c|c|c|c|c|c|c|c|c|c|c|}
\hline & $\begin{array}{c}\mathbf{T} \\
(\varepsilon=2.37)\end{array}$ & $\begin{array}{c}\mathrm{C} \\
(\varepsilon=4.71)\end{array}$ & $\begin{array}{c}\text { CB } \\
(\varepsilon=5.70)\end{array}$ & $\begin{array}{c}\text { DCM } \\
(\varepsilon=8.93)\end{array}$ & $\begin{array}{c}Q \\
(\varepsilon=9.16)\end{array}$ & $\begin{array}{c}E \\
(\varepsilon=24.85)\end{array}$ & $\begin{array}{c}M \\
(\varepsilon=32.61)\end{array}$ & $\begin{array}{c}A \\
(\varepsilon=36.69)\end{array}$ & $\begin{array}{c}\text { DMSO } \\
(\varepsilon=46.83)\end{array}$ & $\begin{array}{c}\text { Water } \\
(\varepsilon=78.36)\end{array}$ \\
\hline \multicolumn{11}{|c|}{ 6-31g(d.p) } \\
\hline Basic & 3.780 & 5.745 & 6.138 & 6.859 & 6.892 & 7.733 & 7.855 & 7.888 & 7.973 & 8.082 \\
\hline $\mathbf{A}$ & 3.603 & 5.957 & 6.465 & 7.437 & 7.483 & 8.705 & 8.891 & 8.943 & 9.075 & 9.249 \\
\hline B & 4.003 & 6.175 & 6.649 & 7.560 & 7.603 & 8.667 & 8.823 & 8.864 & 8.970 & 9.109 \\
\hline $\mathbf{C}$ & 4.119 & 6.156 & 6.580 & 7.386 & 7.425 & 8.459 & 8.618 & 8.663 & 8.778 & 8.929 \\
\hline D & 4.533 & 6.829 & 7.314 & 8.236 & 8.279 & 9.435 & 9.612 & 9.662 & 9.789 & 9.957 \\
\hline $\mathbf{E}$ & 3.894 & 6.224 & 6.716 & 7.645 & 7.689 & 8.849 & 9.025 & 9.075 & 9.201 & 9.367 \\
\hline \multicolumn{11}{|c|}{$6-31 g+(d . p)$} \\
\hline Basic & 4.208 & 6.582 & 7.056 & 7.826 & 7.866 & 8.913 & 9.066 & 9.108 & 9.216 & 9.357 \\
\hline $\mathbf{A}$ & 4.930 & 7.401 & 7.971 & 9.040 & 9.094 & 10.422 & 10.611 & 10.869 & 10.803 & 10.977 \\
\hline B & 4.502 & 6.841 & 7.347 & 8.320 & 8.366 & 9.613 & 9.804 & 9.858 & 9.995 & 10.176 \\
\hline $\mathbf{C}$ & 4.801 & 7.484 & 8.268 & 9.142 & 9.185 & 10.329 & 10.479 & 10.518 & 10.625 & 10.756 \\
\hline D & 5.120 & 8.013 & 8.650 & 9.935 & 9.996 & 11.340 & 11.515 & 11.566 & 11.691 & 11.854 \\
\hline $\mathbf{E}$ & 4.217 & 6.920 & 7.501 & 8.624 & 8.678 & 10.122 & 10.343 & 10.406 & 10.567 & 10.777 \\
\hline \multicolumn{11}{|c|}{$6-311 \mathrm{~g}++(\mathrm{d} . \mathrm{p})$} \\
\hline Basic & 4.162 & 6.416 & 6.881 & 7.747 & 7.788 & 8.820 & 8.970 & 9.012 & 9.120 & 9.261 \\
\hline $\mathbf{A}$ & 4.721 & 7.819 & 8.459 & 9.726 & 9.797 & 9.420 & 9.659 & 9.726 & 9.893 & 11.126 \\
\hline B & 4.497 & 6.858 & 7.363 & 8.343 & 8.389 & 9.659 & 9.852 & 9.883 & 10.048 & 10.232 \\
\hline C & 4.959 & 7.474 & 8.023 & 9.070 & 9.125 & 10.319 & 10.479 & 10.486 & 10.639 & 10.790 \\
\hline D & 5.186 & 8.040 & 8.680 & 9.807 & 9.860 & 11.188 & 11.383 & 11.435 & 11.570 & 11.742 \\
\hline $\mathbf{E}$ & 4.265 & 6.970 & 7.553 & 8.688 & 8.742 & 10.208 & 10.422 & 10.496 & 10.663 & 10.882 \\
\hline
\end{tabular}

\section{2. Physico-Chemical Properties}

The solvation free energy changing ongoing from the gas phase to the water phase for Basic compound and its aromatic substituted derivatives are shown in Figure 2, the numerical data is given in Table 2. Here, it is clear from Figure 2a that the Solvation free energy for the Basic structure increases as the solvent dielectric constant increases, in systematically because of the more dielectric constant causes the more polarization resulting the more stabilization in the molecule. But, this systematic changing in the ordering of the solvation free energy for the Basic structure is not calculated for the basis sets used in this work: the solvation free energy for the $6-31+\mathrm{g} * *$ basis set (it is indicated by red line) is bigger than that of the 6$311++\mathrm{g}^{* *}$ basis set (it is shown by blue line) which is the largest basis set than those of the other basis sets used in this work. Contrary to expectations, as the basis set is increased, the molecule has not become more stable in thermodynamically in according to these results. Here, the important concern is how relative solvation free energy will change by increasing the solvent dielectric constant when one aromatic group is attached to the $\mathrm{C} 1$ position of the Basic compound. It can be seen from Table 2 that there is no systematic changing in the ordering of the solvation free energy of the C1-substituted Basic compound: the free energy changing for these derivatives strongly depends on both the basis set and especially the solvent media. For example, the free energy of these compounds for the toluene has changed in the following order of the $\mathbf{A}(3.603)<\mathbf{B a s i c}(3.780)<\mathbf{E}(3.894)<$ $\mathbf{B}(4.003)<\mathbf{C}(4.119)<\mathbf{D}(4.533)$ at the $6-31 \mathrm{G}^{* *}$ basis set while this ordering is found out as follows: Basic $(4.208)<\mathbf{E}(4.217)<\mathbf{B}(4.502)<\mathbf{C}(4.801)<$ $\mathbf{A}(4.930)<\mathbf{D}(5.120)$ at the $6-31+\mathrm{G}^{* *}$ basis set(solvation free energies are in $\mathrm{kcalmol}^{-1}$ unit). From Table 2, the solvation free energy is calculated in the same order for both the $6-31+\mathrm{g}^{* *}$ and $6-31++\mathrm{g} * *$ basis sets in water phase: Basic $(9.357)<\mathbf{B} \quad(10.232)<\quad \mathbf{C}(10.790)<\quad \mathbf{E}$ $(10.882)<\mathbf{A}(11.126)<\mathbf{D}(11.742)$ for $6-311++\mathrm{g} * *$ basis set and Basic $(9.357)<\mathbf{B}(10.176)<$ $\mathbf{C}(10.756)<\mathbf{E}(10.777)<\mathbf{A}(10.977)<\mathbf{D}(11.854)$ for $6-31+\mathrm{g}^{* *}$ basis set. Even the free energy depends on both the solvent media or on the basis set, it is not wrong to say that of each substituent group makes the Basic structure stabilized, more or less. Also, among the $\mathrm{C} 1$ substituted Basic compound, the structure D containing the polarizable group as the 6-methoxynaphthalene-2- 
yl substitution at $\mathrm{C} 1$ - position of itself is the more stabilized derivative by increasing the solvent dielectric constant for all basis sets used in this work. It is noticed also from Figure $2 d$ that there is a deviation from the structure A for the ethanol, methanol, acetonitrile, and DMSO solvents with the negative imaginary frequency of $-8.30 \mathrm{~cm}^{-1}$, $10.36 \mathrm{~cm}^{-1}, \quad 10.92 \mathrm{~cm}^{-1}$, and $12.30 \mathrm{~cm}^{-1}$
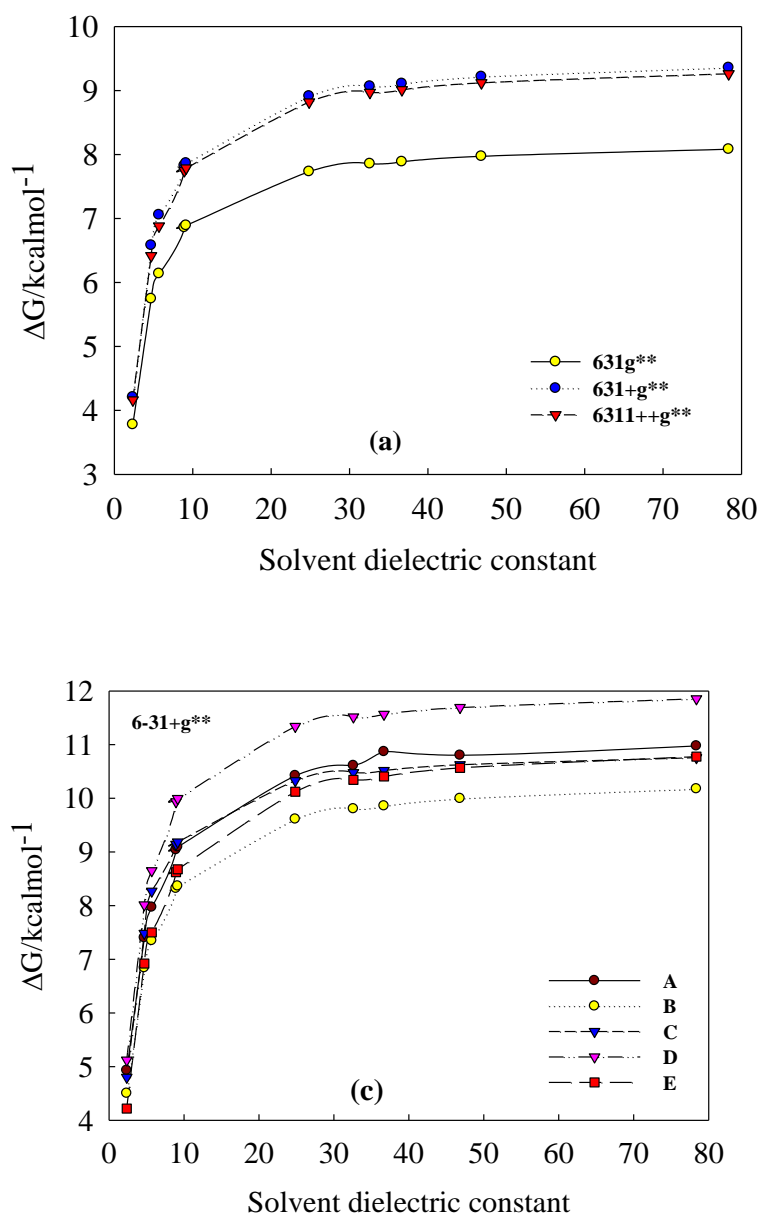

respectively. Although these negative frequencies are not great value, they have affected the free energy. For this reason, the results obtained from these solvents at the $6-311++G(d, p)$ basis set will not be used to predict the chemical reactivity behavior by using the quantum chemical parameters.
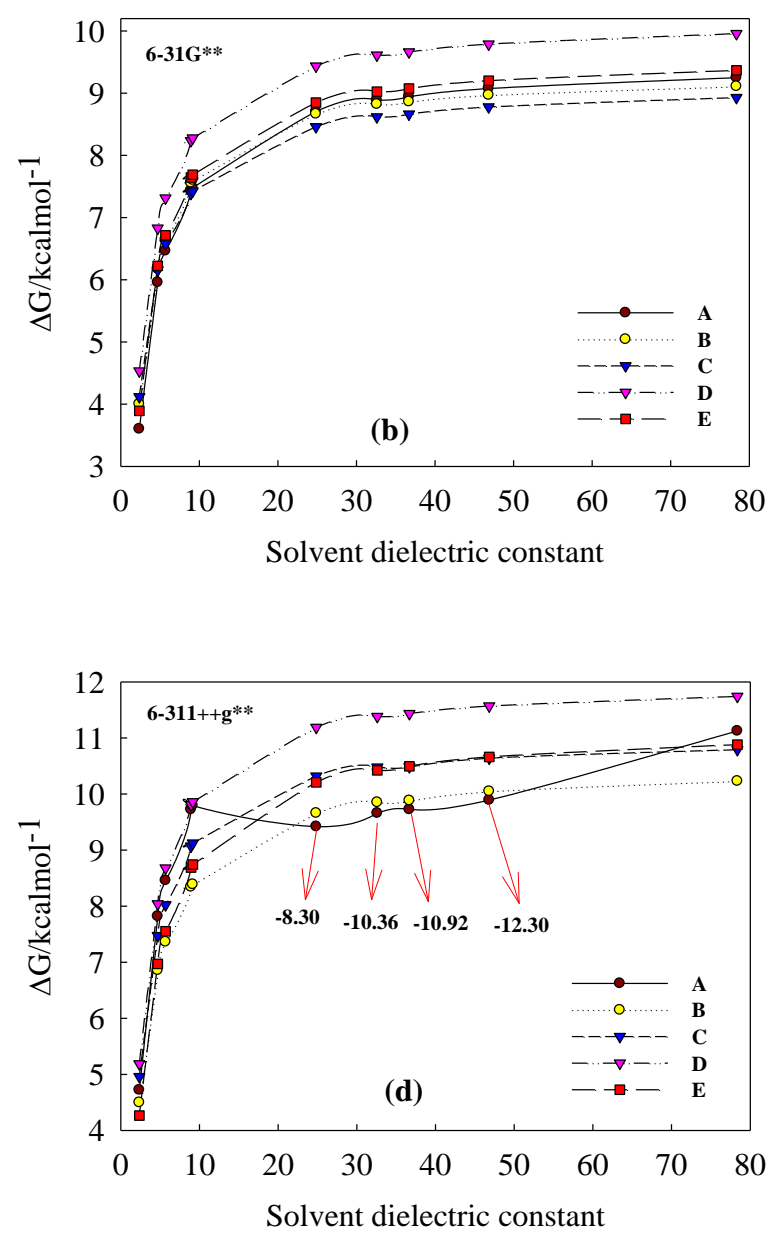

Figure 2. Solvation Free Energies as a function of solvent dielectric constant for Basic compound is given in (a). Solvation Free Energies as a function of solvent dielectric constant for 1-substituted Basic compound derivatives are given at (b) 6-31g $(\mathrm{d}, \mathrm{p})$, (c) 6-31+g(d,p), (d) 6-311++g(d,p) basis sets.

In the many research fields such as biochemical, medicinal, pharmaceutical, biophysical, the solvation free energy has an important role to estimate/evaluate the chemical activity/stability behavior of the molecular systems. The dipole moment based on the electronic structure of any interested molecule is the other physicochemical parameter to predict the chemical stability behavior of the molecular systems. Table 3 has presented the dipole moment of each studied compound obtained from the B3LYP level of theory at three basis sets and in 10 solvent environments. It can be seen from Table 3 that the dipole moment of each compound strongly depends on the solvent media and on the basis set used in this work just like the solvation free energy of them. It can be seen from Table 3 that the dipole moment of each compound strongly depends on the solvent media and on the basis set 
used in this work just like the solvation free energy of them. There is no correlation between the solvation free energy and the dipole moment because the dipole moment values for these compounds are very close to each other. For example, the calculated dipole moment with the 6$311++\mathrm{g}(\mathrm{d}, \mathrm{p})$ basis set changed in the order of Basic $(6.4555)<\mathbf{A}(6.5136)<\mathbf{C}(6.5323)<\mathbf{E}(6.5683)<$ $\mathbf{B}(6.5696)<\mathbf{D}(8.1315)$ for the water phase, but it is calculated as $\mathbf{C}(4.2103)<\mathbf{A}(4.2285)<\mathbf{E}(4.2883)<$ $\mathbf{B}(4.3596)<$ Basic $(4.4844)<\mathbf{D}(5.4614)$ for the gas phase at the same level of the theory. The dipole moment, calculated with 6-31G(d,p) basis set, has increased with the following order: $\mathbf{A}(6.5136)<$ $\mathbf{C}(6.0537)<$ Basic $(6.0604)<\mathbf{E}(6.0777)<\mathbf{B}$ $(6.1067)<\mathbf{D}(7.6947)$ for water phase and the $\mathbf{C}(4.0708)<\mathbf{E}(4.1015)<\mathbf{A}(4.1246)<\mathbf{B}(4.2255)<$ Basic $(4.3178)<\mathbf{D}(5.3181)$ for the gas phase. In according to the Table 3, the compound $\mathbf{D}$, which we previously identified as the most stable molecule in thermodynamically because of its solvation free energy, has the highest dipole moment whatever the solvent is used to calculate the dipole moment of investigated molecules in this work. In the past, Wiberg K. B [33] had determined the electron delocalization energy of some aromatic systems in the following order: Naphthalene (60) < Anthracene (80) < Phenanthrene (85). Although the naphthalene was determined as the less aromatic system because it has the less delocalization energy by Wiberg K. B [33], we can suggest that the methoxy group on substituent part of the compound $\mathbf{D}$ is responsible for the highest dipole moment value resulting in the highest free energy of it.

Table 3. The calculated Dipole Moments (in Debye, D) of both the Basic compound and its C1- substituted derivatives, in 10 solvent environments with 6-31g(d.p), 6-31+g(d.p) and 6-311++g(d.p) basis sets.

\begin{tabular}{|c|c|c|c|c|c|c|c|c|c|c|c|}
\hline & Gas & $\begin{array}{c}\mathbf{T} \\
(\varepsilon=2.37)\end{array}$ & $\begin{array}{c}\mathrm{C} \\
(\varepsilon=4.71)\end{array}$ & $\begin{array}{c}\text { CB } \\
(\varepsilon=5.70)\end{array}$ & $\begin{array}{c}\text { DCM } \\
(\varepsilon=8.93)\end{array}$ & $\begin{array}{c}Q \\
(\varepsilon=9.16)\end{array}$ & $\begin{array}{c}E \\
(\varepsilon=24.85)\end{array}$ & $\begin{array}{c}M \\
(\varepsilon=32.61)\end{array}$ & $\begin{array}{c}\mathrm{A} \\
(\varepsilon=36.69)\end{array}$ & $\begin{array}{c}\text { DMSO } \\
(\varepsilon=46.83)\end{array}$ & $\begin{array}{c}\text { Water } \\
(\varepsilon=78.36)\end{array}$ \\
\hline \multicolumn{12}{|l|}{ 6-31g(d.p) } \\
\hline Basic & 4.3178 & 5.1067 & 5.5330 & 5.6196 & 5.7800 & 5.7873 & 5.9788 & 6.0069 & 6.0147 & 6.0345 & 6.0604 \\
\hline $\mathbf{A}$ & 4.1246 & 4.8936 & 5.3632 & 5.4658 & 5.6637 & 5.6732 & 5.9260 & 5.9649 & 5.9759 & 6.0037 & 6.0405 \\
\hline B & 4.2255 & 5.0089 & 5.4664 & 5.5651 & 5.7537 & 5.7627 & 6.0006 & 6.0367 & 6.0468 & 6.0727 & 6.1067 \\
\hline C & 4.0708 & 4.8831 & 5.3728 & 5.4781 & 5.6789 & 5.6884 & 5.9409 & 5.9794 & 5.9901 & 6.0176 & 6.0537 \\
\hline D & 5.3181 & 6.3033 & 6.8852 & 7.0106 & 7.2498 & 7.2612 & 7.5614 & 7.6069 & 7.6197 & 7.6521 & 7.6947 \\
\hline $\mathbf{E}$ & 4.1015 & 4.9150 & 5.3978 & 5.5020 & 5.7015 & 5.7110 & 5.9638 & 6.0026 & 6.0134 & 6.0411 & 6.0777 \\
\hline \multicolumn{12}{|l|}{$6-31 g+(d . p)$} \\
\hline Basic & 4.5252 & 5.4160 & 5.9074 & 6.0078 & 6.1929 & 6.2015 & 6.4269 & 6.4602 & 6.4695 & 6.4930 & 6.5238 \\
\hline $\mathbf{A}$ & 4.2635 & 5.1451 & 5.7057 & 5.8320 & 6.0797 & 6.0909 & 6.4223 & 6.4747 & 6.4957 & 6.5279 & 6.5788 \\
\hline B & 4.4031 & 5.2871 & 5.8333 & 5.9542 & 6.1887 & 6.2000 & 6.5042 & 6.5515 & 6.5648 & 6.5988 & 6.6438 \\
\hline $\mathbf{C}$ & 4.2520 & 5.1800 & 5.7538 & 5.8819 & 6.1312 & 6.1430 & 6.4630 & 6.5120 & 6.5257 & 6.5607 & 6.6067 \\
\hline D & 5.5239 & 6.6155 & 7.2768 & 7.4208 & 7.6939 & 7.7068 & 8.0521 & 8.1057 & 8.1207 & 8.1594 & 8.2105 \\
\hline $\mathbf{E}$ & 4.3218 & 5.2241 & 5.7859 & 5.9111 & 6.1551 & 6.1669 & 6.4871 & 6.5369 & 6.5508 & 6.5867 & 6.6341 \\
\hline \multicolumn{12}{|c|}{$6-311 \mathrm{~g}++(\mathrm{d} . \mathrm{p})$} \\
\hline Basic & 4.4844 & 5.3632 & 5.8453 & 5.9445 & 6.1292 & 6.1377 & 6.3599 & 6.3927 & 6.4018 & 6.4251 & 6.4555 \\
\hline $\mathbf{A}$ & 4.2285 & 5.1000 & 5.6504 & 5.7752 & 6.0222 & 6.0341 & 6.3631 & 6.4155 & 6.4302 & 6.4681 & 6.5136 \\
\hline B & 4.3596 & 5.2275 & 5.7664 & 5.8858 & 6.1180 & 6.1292 & 6.4309 & 6.4779 & 6.4911 & 6.5249 & 6.5696 \\
\hline $\mathrm{C}$ & 4.2103 & 5.1230 & 5.6913 & 5.8181 & 6.0640 & 6.0757 & 6.3911 & 6.4392 & 6.4527 & 6.4870 & 6.5323 \\
\hline D & 5.4614 & 6.5446 & 7.2013 & 7.3431 & 7.6132 & 7.6260 & 7.9722 & 8.0261 & 8.0413 & 8.0801 & 8.1315 \\
\hline $\mathbf{E}$ & 4.2883 & 5.1723 & 5.7254 & 5.8490 & 6.0918 & 6.1035 & 6.4209 & 6.4706 & 6.4845 & 6.5210 & 6.5683 \\
\hline
\end{tabular}

\section{3. NBO Analysis}

The Natural Bond Orbital (NBO) analysis is used to evaluate the inter- or intra molecular interactions which are important to understand the chemical phenomena such as the hydrogen bonding and electron delocalization from the occupied (donor) molecular orbital to unoccupied molecular (acceptor) orbital, conjugative interactions. [19, 34] Also, the donor and acceptor interactions in the molecular system obtained from the second order Fock matrix in the NBO basis is used to elucidate /explain the chemical stability behavior of the molecular system. The NBO and the idea of the Natural atomic orbital (NAO) analysis is developed by Weinhold and co-workers [35- 36] to derive 
molecular bonds from electron density between atoms by using the one electron density matrix for defining the shape of the atomic orbitals in the molecular orbital environments. The stabilization energy (E2) associated with the delocalization $\mathrm{i} \rightarrow$ $\mathrm{j}$ for each donor (i) and acceptor (j) is determined as

$$
E(2)=\Delta E_{i j}=q i \frac{(F i j)^{2}}{(\varepsilon j-\varepsilon i)}
$$

$\mathrm{qi} \rightarrow$ donor orbital occupancy, $\varepsilon \mathrm{i}, \varepsilon j \rightarrow$ diagonal elements and Fij $\rightarrow$ the off diagonal NBO Fock matrix element.

In this context, we have performed the NBO analysis to elucidate the intramolecular interaction, hybridization, conjugation associated with the donor-acceptor interaction of the substituted compounds. The calculated second order Fock matrix in NBO basis of the Basic molecule and of its substituted derivatives have been summarized in Table 4a and Table 4b. As is known well, the largest $E$ (2) means the stronger interaction between the electron donor and electron acceptor, and the electron delocalization between Lewis (bond or lone pair) and unoccupied non- Lewis (anti-bond or Rydberg) NBO makes the system more stabilized. In according to the Table $4 \mathrm{a}$, one of the most important interaction is calculated for the interaction between the LP (1) N18 $\rightarrow$ (C5-C6) with the stabilization energy of the $94.18 \mathrm{kcalmol}^{-}$ ${ }^{1}$ because the intramolecular charge transfer from the $\mathrm{LP}(1) \mathrm{N}(18)$ to (C5-C6) makes the molecule stabilized due to the $\sigma$ conjugation $\left(\sigma \rightarrow p_{v}\right)$. Another interesting result given in Table $4 \mathrm{a}$ is that there has been calculated the electron donation from donor $\mathrm{LP}(1) \mathrm{N}(18)$ to anti-bonding acceptor (C5- C15), related to the hyperconjugation $(\sigma \rightarrow$ $\pi^{*}$ ), which leads to the strong charge delocalization with the stabilization energy of $46.16 \mathrm{kcalmol}^{-1}$. The calculated E(2) of the Basic structure is mainly due to the interactions $\pi \rightarrow \pi^{*}$ (related to the resonance) occurring from the $\pi$ occupied orbital to the $\pi^{*}$ unoccupied orbital. From Table 4a, the other interaction energies are calculated for the charge transfer to the anti-bond orbital $\mathrm{p}_{\mathrm{v}} \mathrm{C} 5-\mathrm{C} 6$ from the bond orbitals of the $\pi \mathrm{C} 4-\mathrm{N} 17, \pi \mathrm{C} 5-\mathrm{C} 15, \pi \mathrm{C} 11-$ $\mathrm{C} 12, \pi \mathrm{C} 11-\mathrm{N} 17, \pi \mathrm{C} 12-\mathrm{N} 18, \pi \mathrm{C} 13-\mathrm{N} 18, \pi \mathrm{C} 13-$ $\mathrm{C} 19$, and $\pi \mathrm{C} 14-\mathrm{C} 15$ with the stabilization energies of the $3.25,8.31,44.40,10.53,41.40,9.89,12.02$ and $44.12 \mathrm{kcalmol}^{-1}$, in respectively. From Table $4 \mathrm{a}$, the interaction energies of the charge transfer for $\pi \mathrm{C} 19-\mathrm{O} 21 \rightarrow \mathrm{p}_{\mathrm{v}}$ C5-C6 (E(2): $1.77 \mathrm{kcalmol}^{-1}$ with the occupancy of the $0.20886 \mathrm{e}$ ) is relatively lower than the other interaction, but each of them is still quite strong interaction. In addition, the very strong interaction has been computed between the $\mathrm{p}_{\mathrm{v}} \mathrm{C} 3-\mathrm{C} 4$ and the $\mathrm{p}_{\mathrm{v}} \mathrm{C} 5-\mathrm{C} 6$ with the stabilization energy of $63.33 \mathrm{kcalmol}^{-1}$. Also, the other p-p interactions are found out as the $\mathrm{p} \mathrm{C} 3-\mathrm{C} 4 \rightarrow \mathrm{p} \mathrm{C} 1$ $\mathrm{C} 2, \mathrm{p} \mathrm{C} 5-\mathrm{C} 6 \rightarrow \mathrm{p} \mathrm{C} 1-\mathrm{C} 2, \mathrm{p} \mathrm{C} 13-\mathrm{C} 14 \rightarrow \mathrm{p} \mathrm{C} 19-\mathrm{O} 21$ with the stabilization energies of the 11.10, of 9.61, of $10.78 \mathrm{kcalmol}^{-1}$, respectively. If it is looked at the Table $4 a$, it can be easily said that another very strong interaction occurs by the electron donating from the p-type orbital containing the lone pair of the N17 to the antibonding orbital $\mathrm{p}_{\mathrm{v}} \mathrm{C} 5-\mathrm{C} 6$ (with the stabilization energy of the $\left.35.05 \mathrm{kcalmol}^{-1}\right)$. Also, the interactions of $\mathrm{LP}(2) \mathrm{O} 20 \rightarrow \mathrm{p} \mathrm{C} 19-\mathrm{O} 21$ and $\mathrm{LP}(2) \mathrm{O} 21 \rightarrow \pi^{*} \quad \mathrm{C} 19-\mathrm{O} 20$ have the stabilization energies of 24.81 and of 15.23 $\mathrm{kcalmol}^{-1}$ (due to the resonance between the occupied and unoccupied molecular orbitals for both interactions). In according to these results, it can be suggested that the resonance and hyperconjugation effects make the Basic structure the more stabilized than the other interactions. Especially, the interaction between the p-type orbital containing the lone pair and the antibonding orbital $\pi^{*}$ is an important feature and is known well [37-38] that this is necessary to predict the activity behavior of pharmaceutical compounds. 
Table 4a. The selected Second Order Perturbation Theory Analysis Results of the Fock Matrix in NBO Basis for the Basic structure, at B3LYP/6-311++G** in water phase.

\begin{tabular}{|c|c|c|c|c|c|c|c|c|}
\hline Donor(i) & Hybridization & $E^{2} / \mathrm{e}$ & Acceptor (j) & Hybridization & $\mathrm{ED}_{\mathrm{j}} / \mathrm{e}$ & $\mathrm{E}(2)^{\mathrm{a}}$ & $E(j)-E(i)^{b}$ & $F(i, j)^{c}$ \\
\hline $\mathrm{p}_{\mathrm{v}} \mathrm{C} 1-\mathrm{C} 2$ & $0.7197 \mathrm{p}_{(\mathrm{C} 1)}+$ & 0.81564 & $\mathrm{p}_{\mathrm{v}} \mathrm{C} 3-\mathrm{C} 4$ & $\mathrm{p}_{(\mathrm{C} 3)}-\mathrm{p}_{(\mathrm{C} 4)}$ & 0.21090 & 9.21 & 0.27 & 0.064 \\
\hline & $0.6943 \mathrm{p}_{(\mathrm{C} 2)}$ & & $\mathrm{p}_{\mathrm{v}} \mathrm{C5}-\mathrm{C} 6$ & $\mathrm{p}_{(\mathrm{C} 5)}-\mathrm{p}_{(\mathrm{C} 6)}$ & 0.20886 & 46.28 & 0.07 & 0.071 \\
\hline $\mathrm{p}_{\mathrm{v}} \mathrm{C} 3-\mathrm{C} 4$ & $\mathrm{p}_{(\mathrm{C} 3)}-\mathrm{p}_{(\mathrm{C} 4)}$ & 0.81005 & $\mathrm{p}_{\mathrm{v}} \mathrm{C} 1-\mathrm{C} 2$ & $\mathrm{p}_{(\mathrm{C} 1)}-\mathrm{p}_{(\mathrm{C} 2)}$ & 0.19377 & 11.10 & 0.29 & 0.072 \\
\hline & & & $\mathrm{p}_{\mathrm{v}} \mathrm{C5}-\mathrm{C} 6$ & $\mathrm{p}_{(\mathrm{C} 5)}-\mathrm{p}_{(\mathrm{C} 6)}$ & 0.20886 & 63.33 & 0.08 & 0.091 \\
\hline$\pi \mathrm{C} 4-\mathrm{N} 17$ & $\begin{array}{l}0.6115 \mathrm{sp}^{2.68}{ }_{(\mathrm{C} 4)}+ \\
0.7912 \mathrm{sp}^{1.98}{ }_{(\mathrm{N} 17)}\end{array}$ & 0.99097 & $\mathrm{p}_{\mathrm{v}} \mathrm{C} 5-\mathrm{C} 6$ & $\mathrm{p}_{(\mathrm{C} 5)}-\mathrm{p}_{(\mathrm{C} 6)}$ & 0.20886 & 3.25 & 0.62 & 0.064 \\
\hline $\mathrm{p}_{\mathrm{v}} \mathrm{C5-C6}$ & $0.7316 \mathrm{p}_{(\mathrm{C}))^{+}}+$ & 0.81250 & $\mathrm{p}_{\mathrm{v}} \mathrm{C} 1-\mathrm{C} 2$ & $\mathrm{p}_{(\mathrm{C} 1)}-\mathrm{p}_{(\mathrm{C} 2)}$ & 0.19377 & 9.61 & 0.28 & 0.065 \\
\hline & $0.6817 \mathrm{p}_{(\mathrm{C} 6)}$ & & $\mathrm{p}_{\mathrm{v}} \mathrm{C} 3-\mathrm{C} 4$ & $\mathrm{p}_{(\mathrm{C} 3)}-\mathrm{p}_{(\mathrm{C} 4)}$ & 0.21090 & 10.72 & 0.27 & 0.069 \\
\hline$\pi \mathrm{C} 5-\mathrm{C} 15$ & $\begin{array}{l}0.7035 \mathrm{sp}^{2.07}{ }_{(\mathrm{C} 5)}+ \\
0.7107 \mathrm{sp}^{1.98}{ }_{(\mathrm{C} 15)}\end{array}$ & 0.98332 & $\pi *$ C5-C6 & $\mathrm{sp}^{1.69}(\mathrm{C} 5)^{-} \mathrm{sp}^{1.88}(\mathrm{C} 6)$ & 0.01177 & 8.31 & 0.89 & 0.109 \\
\hline$\pi \mathrm{C} 11-\mathrm{C} 12$ & $\begin{array}{l}0.7211 \mathrm{sp}^{1.65}{ }_{(\mathrm{C} 11)^{+}}^{+} \\
0.6929 \mathrm{sp}^{1.69}{ }_{(\mathrm{C} 12)}\end{array}$ & 0.98965 & $\begin{array}{l}p_{v} \text { C5-C6 } \\
p_{v} \text { C13-C14 }\end{array}$ & $\begin{array}{l}\mathrm{p}_{(\mathrm{C} 5)}-\mathrm{p}_{(\mathrm{C} 6)} \\
\mathrm{p}_{(\mathrm{C} 13)}-\mathrm{p}_{(\mathrm{C} 14)}\end{array}$ & $\begin{array}{l}0.20886 \\
0.17266\end{array}$ & $\begin{array}{r}44.40 \\
0.50\end{array}$ & $\begin{array}{l}0.52 \\
0.72\end{array}$ & $\begin{array}{l}0.214 \\
0.026\end{array}$ \\
\hline$\pi \mathrm{C} 11-\mathrm{N} 17$ & $\begin{array}{l}0.6149 \mathrm{sp}^{2.51}{ }_{(\mathrm{C} 11)}+ \\
0.7886 \mathrm{sp}^{1.95}{ }_{(\mathrm{N} 17)}\end{array}$ & 0.99128 & $\mathrm{p}_{\mathrm{v}} \mathrm{C} 5-\mathrm{C} 6$ & $\mathrm{p}_{(\mathrm{C} 5)}-\mathrm{p}_{(\mathrm{C} 6)}$ & 0.20886 & 10.53 & 0.63 & 0.115 \\
\hline$\pi \mathrm{C} 12-\mathrm{N} 18$ & 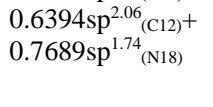 & 0.99191 & $\begin{array}{l}\pi^{*} \text { C1-C6 } \\
p_{v} \text { C5-C6 } \\
\pi^{*} \text { C5-C15 }\end{array}$ & $\begin{array}{l}\mathrm{sp}^{1.79}\left({ }^{1} 1\right)^{-} \mathrm{sp}^{1.75}{ }_{(\mathrm{C} 6)} \\
\mathrm{p}_{(\mathrm{C} 5)-} \mathrm{P}_{(\mathrm{C} 6)} \\
\mathrm{sp}^{2.07}\left({ }_{(\mathrm{C})}\right)^{-} \mathrm{sp}^{1.98}{ }_{(\mathrm{C} 15)}\end{array}$ & $\begin{array}{l}0.00687 \\
0.20886 \\
0.01537\end{array}$ & $\begin{array}{l}13.42 \\
41.40 \\
21.25\end{array}$ & $\begin{array}{l}1.30 \\
0.66 \\
1.20\end{array}$ & $\begin{array}{l}0.167 \\
0.233 \\
0.202\end{array}$ \\
\hline $\mathrm{p}_{\mathrm{v}} \mathrm{C} 13-\mathrm{C} 14$ & $\begin{array}{l}0.7332 \mathrm{p}_{(\mathrm{C} 13)}+ \\
0.6800 \mathrm{p}_{(\mathrm{C} 14)}\end{array}$ & 0.82810 & $\mathrm{p}_{\mathrm{v}} \mathrm{C} 19-\mathrm{O} 21$ & $\mathrm{p}_{(\mathrm{C} 19)}-\mathrm{p}_{(\mathrm{O} 21)}$ & 0.14118 & 10.78 & 0.26 & 0.069 \\
\hline$\pi$ C13-N18 & $\begin{array}{l}0.6442 \mathrm{sp}^{2.18}{ }_{(\mathrm{C} 13)}+ \\
0.7649 \mathrm{sp}^{1.80}{ }_{(\mathrm{N} 18)}\end{array}$ & 0.99170 & $\mathrm{p}_{\mathrm{v}} \mathrm{C} 5-\mathrm{C} 6$ & $\mathrm{p}_{(\mathrm{C} 5)}-\mathrm{p}_{(\mathrm{C} 6)}$ & 0.20886 & 9.89 & 0.65 & 0.113 \\
\hline$\pi \mathrm{C} 13-\mathrm{C} 19$ & $\begin{array}{l}0.7143 \mathrm{sp}^{2.30}{ }_{(\mathrm{C} 13)}^{+} \\
0.6999 \mathrm{sp}^{1.60}{ }_{(\mathrm{C} 19)}\end{array}$ & 0.98658 & $\mathrm{p}_{\mathrm{v}} \mathrm{C} 5-\mathrm{C} 6$ & $\mathrm{p}_{(\mathrm{C} 5)}-\mathrm{p}_{(\mathrm{C} 6)}$ & 0.20886 & 12.02 & 0.54 & 0.114 \\
\hline$\pi \mathrm{C} 14-\mathrm{C} 15$ & $\begin{array}{l}0.6953 \mathrm{sp}^{1.81}{ }_{(\mathrm{C} 14)^{+}}^{+} \\
0.7187 \mathrm{sp}^{1.70}{ }_{(\mathrm{C} 15)}\end{array}$ & 0.98692 & $\mathrm{p}_{\mathrm{v}} \mathrm{C} 5-\mathrm{C} 6$ & $\mathrm{p}_{(\mathrm{C} 5)}-\mathrm{p}_{(\mathrm{C} 6)}$ & 0.20886 & 44.12 & 0.88 & 0.277 \\
\hline$\pi \mathrm{C} 19-\mathrm{O} 21$ & $\begin{array}{l}0.5920 \mathrm{sp}^{1.96}{ }_{(\mathrm{C} 19)}^{+} \\
0.8059 \mathrm{sp}^{1.46}(\mathrm{O} 21)\end{array}$ & 0.99777 & $\mathrm{p}_{\mathrm{v}} \mathrm{C5}-\mathrm{C} 6$ & $\mathrm{p}_{(\mathrm{C} 5)}-\mathrm{p}_{(\mathrm{C} 6)}$ & 0.20886 & 1.77 & 0.91 & 0.057 \\
\hline LP(1) N17 & $\mathrm{p}$ & 0.80218 & $\mathrm{p}_{\mathrm{v}} \mathrm{C} 3-\mathrm{C} 4$ & $\mathrm{p}_{(\mathrm{C} 3)}-\mathrm{p}_{(\mathrm{C} 4)}$ & 0.21090 & 18.24 & 0.31 & 0.095 \\
\hline LP(1) N18 & $\mathrm{sp}^{2.59}$ & 0.95768 & $\begin{array}{l}\mathrm{p}_{\mathrm{v}}<5-\mathrm{Co} \\
\mathrm{p}_{\mathrm{v}} \mathrm{C}-\mathrm{C}-\mathrm{C6}\end{array}$ & $\begin{array}{l}\mathrm{p}_{(\mathrm{C} 5)}-\mathrm{p}_{(\mathrm{C} 6)} \\
\mathrm{p}_{(\mathrm{C} 55)}-\mathrm{p}_{(\mathrm{C})} \\
\mathrm{p}^{2.07}\end{array}$ & $\begin{array}{l}0.20886 \\
0.20886\end{array}$ & $\begin{array}{l}35.05 \\
94.18 \\
4616\end{array}$ & $\begin{array}{l}0.10 \\
0.95 \\
1.49\end{array}$ & $\begin{array}{l}0.077 \\
0.413 \\
0.336\end{array}$ \\
\hline $\mathrm{LP}(2) \mathrm{O} 20$ & $\mathrm{p}$ & 0.89064 & $\mathrm{p}_{\mathrm{v}} \mathrm{C} 19-\mathrm{O} 21$ & $\left.\mathrm{p}_{(\mathrm{C} 19)}\right)^{-} \mathrm{p}_{(\mathrm{O} 21)}$ & 0.14118 & 24.81 & 0.33 & 0.116 \\
\hline $\mathrm{LP}(2) \mathrm{O} 21$ & $\mathrm{p}$ & 0.93004 & $\begin{array}{l}\pi^{*} \mathrm{C} 19-\mathrm{O} 20 \\
\pi^{*} \mathrm{C} 13-\mathrm{C} 19\end{array}$ & $\begin{array}{l}\mathrm{sp}^{2.59}{ }^{2}{ }_{\mathrm{C} 19)^{-}} \mathrm{sp}^{2}{ }_{\mathrm{O} 2020)} \\
\mathrm{sp}^{2.30}{ }_{(\mathrm{C} 13)^{-}} \mathrm{sp}^{1.60}{ }_{(\mathrm{C} 19)}\end{array}$ & $\begin{array}{l}0.04570 \\
0.03504\end{array}$ & $\begin{array}{r}15.23 \\
8.37\end{array}$ & $\begin{array}{l}0.65 \\
0.69\end{array}$ & $\begin{array}{l}0.127 \\
0.097\end{array}$ \\
\hline
\end{tabular}

*a E(2) means the energy of hyper conjugative interaction (stabilization energy), b Energy difference between donor and acceptor $\mathrm{i}$ and $\mathrm{j}$ NBO orbitals, $\mathbf{c} F(\mathrm{i}, \mathrm{j})$ is the fork matrix element between $\mathrm{i}$ and $\mathrm{j} \mathrm{NBO}$ orbitals. 
Table 4b. The selected Second Order Perturbation Theory Analysis Results of the Fock Matrix in NBO Basis for the C1substituted Basic compound derivatives from A- E.

\begin{tabular}{|c|c|c|c|c|c|c|c|c|c|}
\hline \multirow{11}{*}{$\mathbf{A}$} & Donor(i) & Hybridization & $\mathrm{ED}_{\mathrm{i}} / \mathrm{e}$ & Acceptor (j) & Hybridization & $\mathrm{ED}_{\mathrm{j}} / \mathrm{e}$ & $\mathrm{E}(2)^{a}$ & $E(j)-E(i) b$ & $F(i, j)^{c}$ \\
\hline & $\pi \mathrm{C} 5-\mathrm{C} 15$ & $\mathrm{sp}^{2.09}{ }_{(\mathrm{C} 5)}+\mathrm{sp}^{2.02}{ }_{(\mathrm{C} 15)}$ & 0.98132 & $\mathrm{p}_{\mathrm{v}} \mathrm{C} 42-\mathrm{C} 43$ & $\mathrm{p}_{(\mathrm{C} 42)}-\mathrm{p}_{(\mathrm{C} 43)}$ & 0.10901 & 27.82 & 1.48 & 0.268 \\
\hline & $\pi \mathrm{C} 11-\mathrm{C} 12$ & $\mathrm{sp}^{1.63}(\mathrm{C} 11)+\mathrm{sp}^{1.78}(\mathrm{C} 12)$ & 0.98399 & $\mathrm{p}_{\mathrm{v}} \mathrm{C} 19-\mathrm{O} 21$ & $\mathrm{p}_{(\mathrm{C} 19)}-\mathrm{p}_{(\mathrm{O} 21)}$ & 0.14066 & 2.22 & 0.81 & 0.057 \\
\hline & $\pi \mathrm{C} 11-\mathrm{N} 17$ & $\mathrm{sp}^{2.39}(\mathrm{C} 11)+\mathrm{sp}^{1.94}(\mathrm{~N} 17)$ & 0.98513 & $\mathrm{p}_{\mathrm{v}} \mathrm{C} 42-\mathrm{C} 43$ & $\mathrm{p}_{(\mathrm{C} 42)}-\mathrm{p}_{(\mathrm{C} 43)}$ & 0.10901 & 4.69 & 1.46 & 0.110 \\
\hline & $\mathrm{p}_{\mathrm{v}} \mathrm{C} 12-\mathrm{N} 18$ & $\mathrm{p}_{(\mathrm{C} 12)-\mathrm{p}_{(\mathrm{N} 18)}}$ & 0.88847 & $\mathrm{p}_{\mathrm{v}} \mathrm{C} 42-\mathrm{C} 43$ & $\mathrm{p}_{(\mathrm{C} 42)}-\mathrm{p}_{(\mathrm{C} 43)}$ & 0.10901 & 0.52 & 1.49 & 0.037 \\
\hline & $\pi \mathrm{C} 19-\mathrm{O} 20$ & $\mathrm{sp}^{2.58}(\mathrm{C} 19)+\mathrm{sp}^{2}{ }_{(\mathrm{O} 20)}$ & 0.99689 & $\mathrm{p}_{\mathrm{v}} \mathrm{C} 42-\mathrm{C} 43$ & $\mathrm{p}_{(\mathrm{C} 42)}-\mathrm{p}_{(\mathrm{C} 43)}$ & 0.10901 & 50.98 & 7.08 & 0.802 \\
\hline & $\mathrm{p}_{\mathrm{v}} \mathrm{C} 19-\mathrm{O} 21$ & $\mathrm{p}_{(\mathrm{C} 19)}+\mathrm{p}_{(\mathrm{O} 21)}$ & 0.99262 & $\mathrm{p}_{\mathrm{v}} \mathrm{C} 13-\mathrm{C} 14$ & $\mathrm{p}_{(\mathrm{C} 13)^{-}}-\mathrm{p}_{(\mathrm{Cl} 14)}$ & 0.17093 & 1.42 & 0.41 & 0.033 \\
\hline & LP(1) N17 & $\mathrm{p}$ & 0.80309 & $\mathrm{p}_{\mathrm{v}} \mathrm{C} 34-\mathrm{C} 35$ & $\mathrm{p}_{(\mathrm{C} 34)}+\mathrm{p}_{(\mathrm{C} 35)}$ & 0.10907 & 20.81 & 1.76 & 0.253 \\
\hline & LP(1) N18 & $\mathrm{sp}^{2.72}$ & 0.95655 & $\pi^{*} \mathrm{C} 13-\mathrm{C} 14$ & 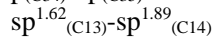 & 0.01393 & 5.29 & 0.89 & 0.088 \\
\hline & $\mathrm{LP}(2) \mathrm{O} 20$ & $\mathrm{p}$ & 0.89017 & $\mathrm{p}_{\mathrm{v}} \mathrm{C} 19-\mathrm{O} 21$ & $\mathrm{p}_{(\mathrm{C} 19)}-\mathrm{p}_{(\mathrm{O} 21)}$ & 0.14066 & 22.91 & 0.27 & 0.100 \\
\hline & $\mathrm{LP}(2) \mathrm{O} 21$ & $\mathrm{p}$ & 0.92980 & $\pi * \mathrm{C} 13-\mathrm{C} 19$ & $\mathrm{sp}^{2.30}(\mathrm{C} 13)^{-} \mathrm{sp}^{1.61}(\mathrm{C} 19)$ & 0.03547 & 8.52 & 0.68 & 0.098 \\
\hline \multirow{10}{*}{ B } & $\pi \mathrm{C} 5-\mathrm{C} 15$ & 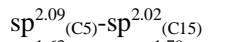 & 0.98138 & $\mathrm{p}_{\mathrm{v}} \mathrm{C} 34-\mathrm{C} 35$ & $\mathrm{p}_{(\mathrm{C} 34)}-\mathrm{p}_{(\mathrm{C} 35)}$ & 0.12383 & 12.56 & 0.30 & 0.082 \\
\hline & $\pi \mathrm{C} 11-\mathrm{C} 12$ & $\mathrm{sp}^{1.63}(\mathrm{C} 11)+\mathrm{sp}^{1.79}(\mathrm{C} 12)$ & 0.98367 & $\mathrm{p}_{\mathrm{v}} \mathrm{C} 34-\mathrm{C} 35$ & $\mathrm{p}_{(\mathrm{C} 34)}-\mathrm{p}_{(\mathrm{C} 35)}$ & 0.12383 & 0.49 & 0.34 & 0.017 \\
\hline & $\pi \mathrm{C} 11-\mathrm{N} 17$ & $\mathrm{sp}^{2.39}(\mathrm{C} 11)+\mathrm{sp}^{1.94}(\mathrm{~N} 17)$ & 0.98518 & $\mathrm{p}_{\mathrm{v}} \mathrm{C} 34-\mathrm{C} 35$ & $\mathrm{p}_{(\mathrm{C} 34)}-\mathrm{p}_{(\mathrm{C} 35)}$ & 0.12383 & 9.07 & 0.40 & 0.081 \\
\hline & $\mathrm{p}_{\mathrm{v}} \mathrm{C} 12-\mathrm{N} 18$ & $\mathrm{p}_{(\mathrm{C} 12)} \mathrm{p}_{(\mathrm{N} 18)}$ & 0.88765 & $\mathrm{p}_{\mathrm{v}} \mathrm{C} 13-\mathrm{C} 14$ & $\mathrm{p}_{(\mathrm{C} 13)-} \mathrm{p}_{(\mathrm{C} 14)}$ & 0.17041 & 12.78 & 0.27 & 0.077 \\
\hline & $\pi \mathrm{C} 19-\mathrm{O} 20$ & $\mathrm{sp}^{2.58}{ }_{(\mathrm{C} 19)}+\mathrm{sp}_{(\mathrm{O} 20)}^{2}$ & 0.99690 & $\mathrm{p}_{\mathrm{v}} \mathrm{C} 19-\mathrm{O} 21$ & $\mathrm{p}_{(\mathrm{C} 19)}-\mathrm{p}_{(\mathrm{O} 21)}$ & 0.14085 & 9.06 & 3.49 & 0.242 \\
\hline & $\pi \mathrm{C} 19-\mathrm{O} 21$ & $\mathrm{sp}^{1.96}(\mathrm{C} 19)+\mathrm{sp}^{1.46}(\mathrm{O} 20)$ & 0.99785 & $\mathrm{p}_{\mathrm{v}} \mathrm{C} 32-\mathrm{C} 33$ & $\mathrm{p}_{(\mathrm{C} 32)}-\mathrm{p}_{(\mathrm{C} 33)}$ & 0.12638 & 8.22 & 0.38 & 0.076 \\
\hline & LP(1) N17 & $\mathrm{p}$ & 0.80310 & $\mathrm{p}_{\mathrm{v}} \mathrm{C} 19-\mathrm{O} 21$ & $\mathrm{p}_{(\mathrm{C} 19)}-\mathrm{p}_{(\mathrm{O} 21)}$ & 0.14085 & 14.01 & 5.87 & 0.373 \\
\hline & LP(1) N18 & $\mathrm{sp}^{2.68}$ & 0.95672 & $\pi^{*} \mathrm{C} 13-\mathrm{C} 14$ & $\mathrm{sp}^{1.62}(\mathrm{C} 13)^{-} \mathrm{sp}^{1.89}{ }_{(\mathrm{C} 14)}$ & 0.01393 & 12.16 & 0.27 & 0.074 \\
\hline & $\mathrm{LP}(2) \mathrm{O} 20$ & $\mathrm{p}$ & 0.89027 & $\mathrm{p}_{\mathrm{v}} \mathrm{C} 19-\mathrm{O} 21$ & $\mathrm{p}_{(\mathrm{C} 19)}-\mathrm{p}_{(\mathrm{O} 21)}$ & 0.14085 & 25.85 & 0.29 & 0.110 \\
\hline & $\mathrm{LP}(1) \mathrm{O} 21$ & $\mathrm{sp}^{0.68}$ & 0.99012 & $\sigma * \mathrm{C} 39-\mathrm{H} 46$ & $\mathrm{sp}^{2.51}(\mathrm{C} 39)^{-} \mathrm{S}_{(\mathrm{H} 46)}$ & 0.00667 & 27.82 & 0.04 & 0.045 \\
\hline \multirow{10}{*}{$\mathbf{C}$} & $\pi \mathrm{C} 5-\mathrm{C} 15$ & $\mathrm{sp}^{2.08}{ }_{(\mathrm{C} 5)}+\mathrm{sp}^{1.97}(\mathrm{C} 15)$ & 0.98295 & $\mathrm{p}_{\mathrm{v}} \mathrm{C} 19-\mathrm{O} 21$ & $\mathrm{p}_{(\mathrm{C} 19)}-\mathrm{p}_{(\mathrm{O} 21)}$ & 0.14046 & 0.31 & 0.76 & 0.021 \\
\hline & $\pi \mathrm{C} 11-\mathrm{C} 12$ & $\mathrm{Sp}^{1.62}(\mathrm{C} 11)+\mathrm{sp}^{1.79}{ }_{\mathrm{C} 12)}$ & 0.98661 & $\mathrm{p}_{\mathrm{v}} \mathrm{C} 35-\mathrm{C} 36$ & $\mathrm{p}_{(\mathrm{C} 35)}-\mathrm{p}_{(\mathrm{C} 36)}$ & 0.12528 & 3.30 & 0.82 & 0.070 \\
\hline & $\pi \mathrm{C} 11-\mathrm{N} 17$ & $\mathrm{sp}^{2.51}(\mathrm{C} 11)+\mathrm{sp}^{1.94}(\mathrm{~N} 17)$ & 0.99122 & $\mathrm{p}_{\mathrm{v}} \mathrm{C} 35-\mathrm{C} 36$ & $\mathrm{p}_{(\mathrm{C} 35)}-\mathrm{p}_{(\mathrm{C} 36)}$ & 0.12528 & 0.75 & 0.75 & 0.032 \\
\hline & $\mathrm{p}_{\mathrm{v}} \mathrm{C} 12-\mathrm{N} 18$ & $\mathrm{p}_{(\mathrm{C} 12)} \mathrm{p}_{(\mathrm{N} 18)}$ & 0.88259 & $\mathrm{p}_{\mathrm{v}} \mathrm{C} 13-\mathrm{C} 14$ & $\mathrm{p}_{(\mathrm{C} 13)}-\mathrm{p}_{(\mathrm{C} 14)}$ & 0.17293 & 10.23 & 0.33 & 0.076 \\
\hline & $\pi \mathrm{C} 19-\mathrm{O} 20$ & $\mathrm{sp}^{2.58}{ }_{(\mathrm{C} 19)}+\mathrm{sp}_{(\mathrm{O} 20)}^{2}$ & 0.99677 & $\mathrm{p}_{\mathrm{v}} \mathrm{C} 38-\mathrm{C} 39$ & $\mathrm{p}_{(\mathrm{C} 38)}-\mathrm{p}_{(\mathrm{C} 39)}$ & 0.11843 & 1.99 & 2.42 & 0.093 \\
\hline & $\pi \mathrm{C} 19-\mathrm{O} 21$ & $\mathrm{sp}^{1.96}(\mathrm{C} 19)+\mathrm{sp}^{1.46}(\mathrm{O} 21)$ & 0.99775 & $\mathrm{p}_{\mathrm{v}} \mathrm{C} 35-\mathrm{C} 36$ & $\mathrm{p}_{(\mathrm{C} 35)}-\mathrm{p}_{(\mathrm{C} 36)}$ & 0.12528 & 22.68 & 2.20 & 0.301 \\
\hline & LP(1) N17 & $\mathrm{p}$ & 0.80277 & $\mathrm{p}_{\mathrm{v}} \mathrm{C} 38-\mathrm{C} 39$ & $\mathrm{p}_{(\mathrm{C} 38)}-\mathrm{p}_{(\mathrm{C} 39)}$ & 0.11843 & 102.66 & 6.95 & 1.111 \\
\hline & LP(1) N18 & $\mathrm{sp}^{2.70}$ & 0.95583 & $\mathrm{p}_{\mathrm{v}} \mathrm{C} 38-\mathrm{C} 39$ & $\mathrm{p}_{(\mathrm{C} 38)}-\mathrm{p}_{(\mathrm{C} 39)}$ & 0.11843 & 135.82 & 55.25 & 3.594 \\
\hline & $\mathrm{LP}(1) \mathrm{O} 20$ & $\mathrm{sp}^{1.59}$ & 0.98151 & $\mathrm{p}_{\mathrm{v}} \mathrm{C} 38-\mathrm{C} 39$ & $\mathrm{p}_{(\mathrm{C} 38)}-\mathrm{p}_{(\mathrm{C} 39)}$ & 0.11843 & 46.82 & 3.06 & 0.504 \\
\hline & $\mathrm{LP}(2) \mathrm{O} 21$ & $\mathrm{p}$ & 0.92993 & $\mathrm{p}_{\mathrm{v}} \mathrm{C} 38-\mathrm{C} 39$ & $\mathrm{p}_{(\mathrm{C} 38)}-\mathrm{p}_{(\mathrm{C} 39)}$ & 0.11843 & 175.59 & 5.69 & 1.293 \\
\hline \multirow{10}{*}{ D } & $\pi \mathrm{C} 5-\mathrm{C} 15$ & $\mathrm{sp}^{2.06}{ }_{(\mathrm{C} 5)}+\mathrm{sp}^{2.01}{ }_{(\mathrm{C} 15)}$ & 0.98289 & $\sigma^{*}$ C39-H50 & $\left.\mathrm{sp}^{2.50}{ }_{(\mathrm{C} 39)}\right)^{-} \mathrm{S}_{(\mathrm{H} 50)}$ & 0.00666 & 37.26 & 0.14 & 0.091 \\
\hline & $\pi \mathrm{C} 11-\mathrm{C} 12$ & $\mathrm{sp}^{1.61}(\mathrm{C} 11)+\mathrm{sp}^{1.81}(\mathrm{C} 12)$ & 0.98701 & $\mathrm{p}_{\mathrm{v}} \mathrm{C} 31-\mathrm{C} 32$ & $\mathrm{p}_{(\mathrm{C} 31)}-\mathrm{p}_{(\mathrm{C} 32)}$ & 0.14187 & 0.64 & 0.50 & 0.024 \\
\hline & $\pi \mathrm{C} 11-\mathrm{N} 17$ & $\mathrm{sp}^{2.52}(\mathrm{C} 11)+\mathrm{sp}^{1.94}(\mathrm{~N} 17)$ & 0.99120 & $\pi *$ C30-C39 & $\mathrm{sp}^{1.89}(\mathrm{C} 30)^{-} \mathrm{sp}_{(\mathrm{C} 39)}^{2}$ & 0.01366 & 36.60 & 0.92 & 0.232 \\
\hline & $\mathrm{p}_{\mathrm{v}} \mathrm{C} 12-\mathrm{N} 18$ & $\mathrm{p}_{(\mathrm{C} 12)-\mathrm{p}_{(\mathrm{N} 18)}}$ & 0.88217 & $\mathrm{p}_{\mathrm{v}} \mathrm{C} 13-\mathrm{C} 14$ & $\mathrm{p}_{(\mathrm{C} 13)-\mathrm{p}_{(\mathrm{C} 14)}}$ & 0.17315 & 10.71 & 0.33 & 0.077 \\
\hline & $\pi \mathrm{C} 19-\mathrm{O} 20$ & $\mathrm{sp}^{2.58}(\mathrm{C} 19)+\mathrm{sp}^{2}{ }_{(\mathrm{O} 20)}$ & 0.99676 & $\mathrm{p}_{\mathrm{v}} \mathrm{C} 33-\mathrm{C} 34$ & $\mathrm{p}_{(\mathrm{C} 33)}-\mathrm{p}_{(\mathrm{C} 34)}$ & 0.13628 & 334.55 & 0.09 & 0.239 \\
\hline & $\pi \mathrm{C} 19-\mathrm{O} 21$ & $\mathrm{sp}^{1.96}(\mathrm{C} 19)+\mathrm{sp}^{1.46}(\mathrm{O} 21)$ & 0.99773 & $\mathrm{p}_{\mathrm{v}} \mathrm{C} 33-\mathrm{C} 34$ & $\mathrm{p}_{(\mathrm{C} 33)}-\mathrm{p}_{(\mathrm{C} 34)}$ & 0.13628 & 558.36 & 1.59 & 1.279 \\
\hline & LP(1) N17 & $\mathrm{p}$ & 0.80298 & $\mathrm{p}_{\mathrm{v}} \mathrm{C} 3-\mathrm{C} 4$ & $\mathrm{p}_{(\mathrm{C} 3)}-\mathrm{p}_{(\mathrm{C} 4)}$ & 0.21198 & 20.31 & 0.28 & 0.096 \\
\hline & LP(1) N18 & $\mathrm{sp}^{2.68}$ & 0.95545 & $\pi^{*} \mathrm{C} 11-\mathrm{C} 12$ & $\mathrm{sp}^{1.61}(\mathrm{C} 11)^{-} \mathrm{Sp}^{1.81}(\mathrm{C} 12)$ & 0.01992 & 4.76 & 0.87 & 0.082 \\
\hline & $\mathrm{LP}(2) \mathrm{O} 20$ & $\mathrm{p}$ & 0.89030 & $\mathrm{p}_{\mathrm{v}} \mathrm{C} 19-\mathrm{O} 21$ & $\mathrm{p}_{(\mathrm{C} 19)}-\mathrm{p}_{(\mathrm{O} 21)}$ & 0.14054 & 41.65 & 0.33 & 0.149 \\
\hline & $\mathrm{LP}(1) \mathrm{O} 21$ & $\mathrm{sp}^{0.68}$ & 0.99012 & $\pi * \mathrm{C} 13-\mathrm{C} 19$ & $\mathrm{sp}^{2.31}(\mathrm{C} 13)^{-\mathrm{Sp}^{1.60}}(\mathrm{C} 19)$ & 0.03534 & 5.77 & 0.27 & 0.050 \\
\hline \multirow{10}{*}{$\mathbf{E}$} & $\pi \mathrm{C} 5-\mathrm{C} 15$ & $\mathrm{sp}^{2.06}{ }_{(\mathrm{C} 5)}+\mathrm{sp}_{(\mathrm{C} 15)}$ & 0.98307 & $\mathrm{p}_{\mathrm{v}} \mathrm{C} 30-\mathrm{C} 31$ & $\mathrm{p}_{(\mathrm{C} 30)}-\mathrm{p}_{(\mathrm{C} 31)}$ & 0.10557 & 0.32 & 1.79 & 0.032 \\
\hline & $\pi \mathrm{C} 11-\mathrm{C} 12$ & $\mathrm{sp}^{1.64}(\mathrm{C} 11)+\mathrm{sp}^{1.79}(\mathrm{C} 12)$ & 0.98322 & $\mathrm{p}_{\mathrm{v}} \mathrm{C} 30-\mathrm{C} 31$ & $\mathrm{p}_{(\mathrm{C} 30)}-\mathrm{p}_{(\mathrm{C} 31)}$ & 0.10557 & 20.50 & 1.77 & 0.252 \\
\hline & $\pi \mathrm{C} 11-\mathrm{N} 17$ & $\mathrm{sp}^{2.39}(\mathrm{C} 11)+\mathrm{sp}^{1.97}(\mathrm{~N} 17)$ & 0.98512 & $\mathrm{p}_{\mathrm{v}} \mathrm{C} 30-\mathrm{C} 31$ & $\mathrm{p}_{(\mathrm{C} 30)}-\mathrm{p}_{(\mathrm{C} 31)}$ & 0.10557 & 11.04 & 1.93 & 0.193 \\
\hline & $\mathrm{p}_{\mathrm{v}} \mathrm{C} 12-\mathrm{N} 18$ & $\mathrm{p}_{(\mathrm{C} 12)-} \mathrm{p}_{(\mathrm{N} 18)}$ & 0.88719 & $\mathrm{p}_{\mathrm{v}} \mathrm{C} 13-\mathrm{C} 14$ & $\mathrm{p}_{(\mathrm{C} 13)}-\mathrm{p}_{(\mathrm{C} 14)}$ & 0.17175 & 9.15 & 0.33 & 0.071 \\
\hline & $\pi \mathrm{C} 19-\mathrm{O} 20$ & $\mathrm{sp}^{2.58}{ }_{(\mathrm{C} 19)}+\mathrm{sp}_{(\mathrm{O} 20)}$ & 0.99677 & $\mathrm{p}_{\mathrm{v}} \mathrm{C} 40-\mathrm{C} 41$ & $\mathrm{p}_{(\mathrm{C} 40)}-\mathrm{p}_{(\mathrm{C} 41)}$ & 0.13758 & 249.65 & 0.02 & 0.090 \\
\hline & $\pi \mathrm{C} 19-\mathrm{O} 21$ & $\mathrm{sp}^{1.96}(\mathrm{C} 19)+\mathrm{sp}^{1.46}(\mathrm{O} 21)$ & 0.99762 & $\mathrm{p}_{\mathrm{v}} \mathrm{C} 40-\mathrm{C} 41$ & $\mathrm{p}_{(\mathrm{C} 40)}-\mathrm{p}_{(\mathrm{C} 41)}$ & 0.13758 & 114.91 & 1.72 & 0.604 \\
\hline & LP(1) N17 & $\mathrm{p}$ & 0.80358 & $\mathrm{p}_{\mathrm{v}} \mathrm{C} 40-\mathrm{C} 41$ & $\mathrm{p}_{(\mathrm{C} 40)}-\mathrm{p}_{(\mathrm{C} 41)}$ & 0.13758 & 343.42 & 9.46 & 2.345 \\
\hline & LP(1) N18 & $\mathrm{sp}^{2.70}$ & 0.95671 & $\mathrm{p}_{\mathrm{v}} \mathrm{C} 30-\mathrm{C} 31$ & $\mathrm{p}_{(\mathrm{C} 30)}-\mathrm{p}_{(\mathrm{C} 31)}$ & 0.10557 & 363.60 & 3.03 & 1.368 \\
\hline & $\mathrm{LP}(2) \mathrm{O} 20$ & $\mathrm{p}$ & 0.89015 & $\mathrm{p}_{\mathrm{v}} \mathrm{C} 19-\mathrm{O} 21$ & $\mathrm{p}_{(\mathrm{C} 19)}-\mathrm{p}_{(\mathrm{O} 21)}$ & 0.14060 & 24.79 & 0.34 & 0.117 \\
\hline & $\mathrm{LP}(2) \mathrm{O} 21$ & $\mathrm{p}$ & 0.92987 & $\mathrm{p}_{\mathrm{v}} \mathrm{C} 30-\mathrm{C} 31$ & $\mathrm{p}_{(\mathrm{C} 30)}-\mathrm{p}_{(\mathrm{C} 31)}$ & 0.10557 & 8.60 & 1.41 & 0.142 \\
\hline
\end{tabular}

*a E(2) means the energy of hyper conjugative interaction (stabilization energy), b Energy difference between donor and acceptor i and $\mathrm{j}$ NBO orbitals, $\mathbf{c} F(i, j)$ is the fork matrix element between $i$ and $j$ NBO orbitals.

Up to now, we have tried to show the possible strong theory in the water phase. The highest electron interactions providing the stabilization in the Basic delocalization among the C1-substituted Basic structure. Now, it is worthwhile to discuss how these compound derivatives is determined for the $\mathbf{D}$ with interactions change with the substituent group $\pi \mathrm{C} 19-\mathrm{O} 21 \rightarrow \mathrm{p}_{\mathrm{v}} \mathrm{C} 33-\mathrm{C} 34$ with the stabilization attached to the Basic structure. Table $4 \mathrm{~b}$ has energy of the $558.36 \mathrm{kcalmol}^{-1}$. Moreover, the summarized the possible strong interaction for the interaction energy for the $\pi \mathrm{C} 15-\mathrm{C} 15 \rightarrow \sigma^{*} \mathrm{C} 39-\mathrm{H} 50$ structures A to $\mathbf{E}$, at B3LYP/6-311++G** level of for the compound $\mathbf{D}$ is found out as $37.26 \mathrm{kcalmol}^{-1}$ 
due to this interaction makes the system stabilized by the negative hyperconjugation which occurs the charge transfer from the occupied orbital $\pi$ to the unoccupied orbital $\sigma^{*}$. On the other hand, second highest electron delocalization energy is determined for the structure $\mathbf{E}$ : the interaction of $\mathrm{LP}(1) \mathrm{N} 18 \rightarrow \mathrm{p}_{\mathrm{v}}$ C30-C31 has the stabilization energy of the 363.60 $\mathrm{kcalmol}^{-1}$ due to the phenanthrene-9-yl substitution on the $\mathrm{C} 1$-position of the Basic structure makes the electron delocalization on the substituted compound enhances. The interaction energy of the $\pi \mathrm{C} 5-\mathrm{C} 15 \rightarrow$ $\pi^{*} \mathrm{C} 34-\mathrm{C} 35$ for $\mathbf{B}$ is around of the $12.56 \mathrm{kcalmol}^{-1}$ (with the occupancy of $0.12383 \mathrm{e}$ ), but this interaction is not observed for the $\mathbf{C}$. Instead of the interaction $\pi \mathrm{C} 5-\mathrm{C} 15 \rightarrow \pi^{*} \mathrm{C} 34-\mathrm{C} 35$, the interactions of $\pi \mathrm{C} 5-\mathrm{C} 15 \rightarrow \pi^{*} \mathrm{C} 42-\mathrm{C} 43$ for the $\mathrm{A}$ and of $\pi \mathrm{C} 5-\mathrm{C} 15 \rightarrow \pi^{*} \mathrm{C} 30-\mathrm{C} 31$ for $\mathbf{E}$ have been observed with stabilization energies of the 27.82 $\mathrm{kcalmol}^{-1}$ and of the $0.32 \mathrm{kcalmol}^{-1}$, respectively. The charge transfer of $p_{v} \mathrm{C} 12-\mathrm{N} 18 \rightarrow \mathrm{p}_{\mathrm{v}} \mathrm{C} 13-\mathrm{C} 14$ for the compounds $\mathbf{B}, \mathbf{C}, \mathbf{D}$ and $\mathbf{E}$ has changed from 9.15 to $12.78 \mathrm{kcalmol}^{-1}$, this interaction is not calculated for the Basic structure. The charge transfer from the $\mathrm{LP}(2) \mathrm{O} 20$ to the antibonding $\mathrm{p}_{\mathrm{v}}$ C19-O21 is calculated for the structures $\mathbf{A}, \mathbf{B}, \mathbf{D}$ and $\mathbf{E}$ with the stabilization energy of $22.91,25.85$, 41.65 and $24.79 \mathrm{kcalmol}^{-1}$, respectively. It can be said that the charge transfer between LP(2) O20 and $\mathrm{p}_{\mathrm{v}} \mathrm{C} 19-\mathrm{O} 21$ for the structure $\mathbf{D}$ is two times more than those of the other substituted compounds, also that the maximum electron density for this interaction changed from $0.89015 \mathrm{e}$ to $0.89030 \mathrm{e}$ in electron donor orbital. Here, we should also express that the maximum electron delocalization from the LP(1) N17 with the occupancy 0.80298 e to $p_{v}$ C3$\mathrm{C} 4$ of with occupancy $0.21198 \mathrm{e}$ is calculated for the structure D with the stabilization energy of 20.31 $\mathrm{kcalmol}^{-1}$. In this work, it has shown some important interactions resulting in the stabilization.

\section{4. Frontier Molecular Orbital Analysis}

Frontier molecular orbitals called both the Highest occupied molecular orbital and the lowest unoccupied molecular orbital are very important parameters used in prediction of the way the molecule interacts with the other species [39]: the HOMO as the electron donor is responsible for donating the electron to the outer species and LUMO as the electron acceptor represents the ability to accept the electron from the outer species. Therefore, the HOMO is directly related to the Ionization potential and the LUMO is related to the electron affinity. In this work, the frontier orbital analysis has been investigated both with three basis sets and in the 10 solvent environments, too. The results obtained from quantum chemical calculations have shown that the frontier molecular orbitals' shape for each compound is very similar to each other for both the basis sets and the solvent environments, but the numerical results of them are different from each other. Here, it is given in Figure 3 the HOMO and of the LUMO amplitudes calculated at the B3LYP/6-311++G** level of theory in the aqueous phase for both the Basic compound and its $\mathrm{C} 1$ substituted derivatives. 


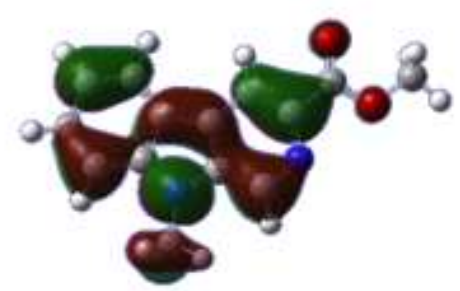

Basic

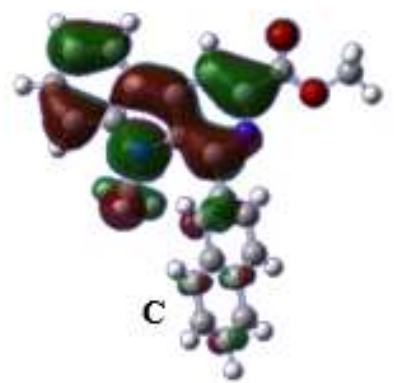

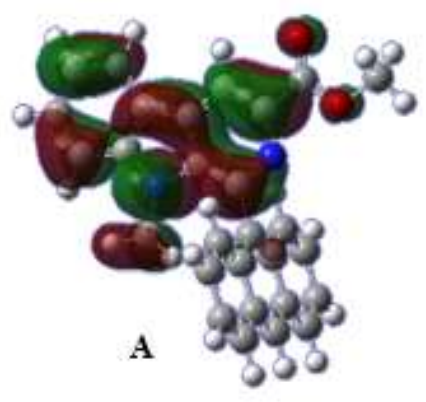

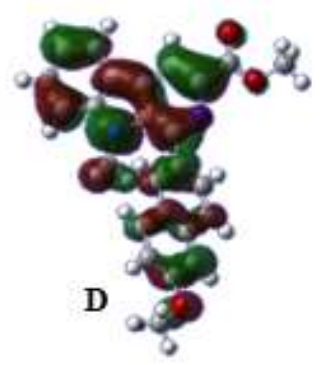

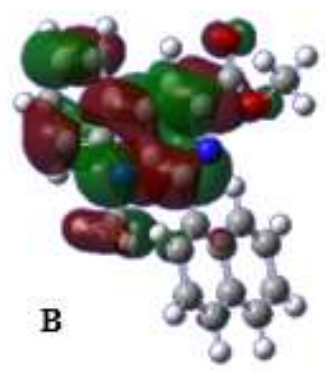

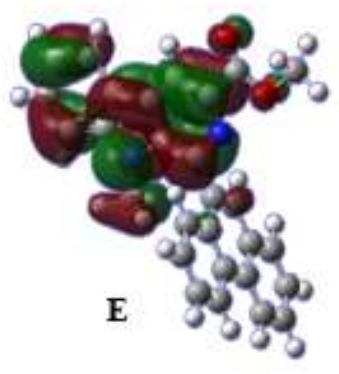

Figure 3a. HOMO amplitudes for both the Basic compound and its $\mathrm{C} 1$ substituted derivatives calculated at the B3LYP/6$311++\mathrm{G}^{* *}$ level of theory in the aqueous phase.

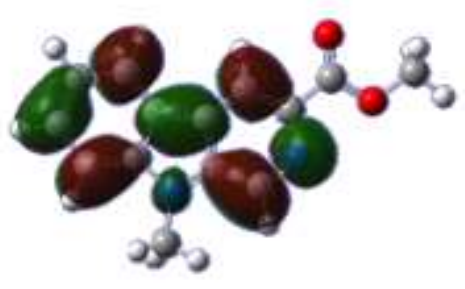

Basic

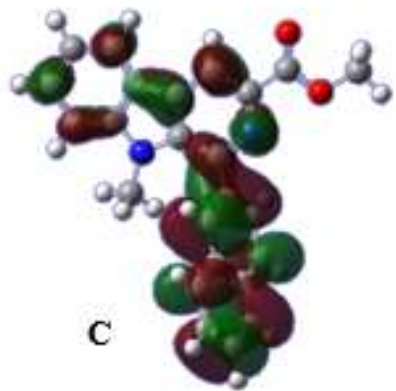

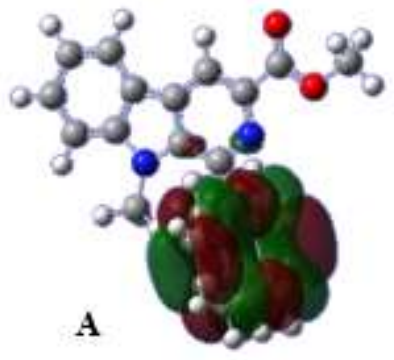

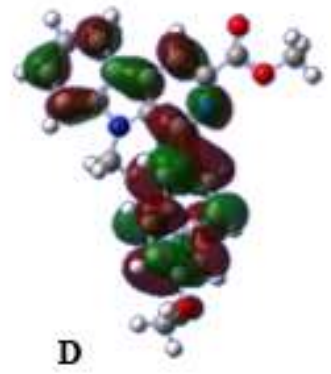

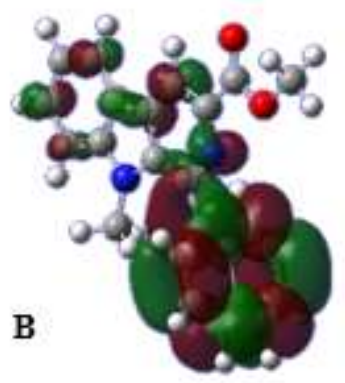

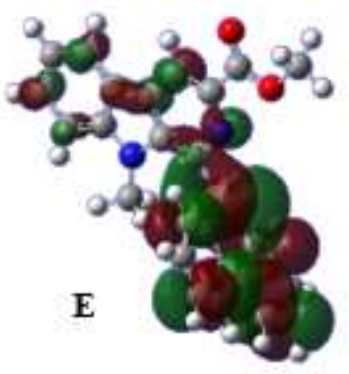

Figure 3b. LUMO amplitudes for both the Basic molecule and its C1 substituted derivatives calculated at the B3LYP/6-311++G** level of theory in the aqueous phase.

From Figure 3a, for the Basic compound, the HOMO is localized on the full molecular surface of the Basic structure except for the methyl group at C3-position of this compound, which means if there is a nucleophilic attack reaction to any molecule/ to the receptor site, then this compound will attack with the electrons located on its HOMO to outer species. On the other hand, from Figure $3 b$, the LUMO is only localized on the aromatic site of this structure, which means the electrophilic attack 
to this structure will occur in this location. At this point, it is worthwhile to ask how the HOMO and LUMO amplitudes on the Basic structure change when the substituent group is attached to $\mathrm{C} 1$ position of the Basic structure. It is clear from Figure $3 \mathrm{a}$ that the HOMO amplitude for each $\mathrm{C} 1$ substituted compounds is very like the Basic structural units' HOMO amplitude, except for the structure $\mathbf{D}$, but just a little HOMO is localized on the substituent part of each structure, too. For the structure $\mathbf{D}$, the HOMO is localized on the whole molecule including the Basic unit, and the substituent group, too. Therefore, it can be suggested that the structure $\mathbf{D}$ has the highest electron delocalization than that of the other $\mathrm{C} 1$ substituted derivatives. On the other hand, the LUMO amplitude for each substituted derivative is different from each other. First, it should be expressed that the carboxymethyl group at C3position and - $\mathrm{CH} 3$ group at N9-position are not very effective for electrophilic attack reactions because there is no any LUMO localization on these groups both Basic structure and of its substituted derivatives. Second, the LUMO is localized on the entire molecule for the structure $\mathbf{D}$, that is, it should be kept in mind the $\mathbf{D}$ has the highest dipole moment resulting in the highest thermodynamic stability as it was stated in the free energy section of this work before. Finally, for the structure A, the LUMO is only localized on the substituent group which is anthracene 9-yl substitution at C1-position of the Basic structure, therefore the electrophilic attack center shifts from the Basic part to the substituent part.

\section{5. The Calculated Quantum Chemical Parameters}

Until now, we have discussed the sites which the investigated molecules worked to be effective via both the FMO visualization, also we have investigated the structural parameters, solvation free energy, dipole moments and NBO analysis to predict the chemical reactivity behavior of all compounds. Nowadays, the calculated quantum chemical parameters are discussed to explain the chemical reactivity behavior of all compounds because quantum chemical parameters are getting commonly used to predict/explain the chemical behavior of the molecular systems. In this context, the calculated global descriptors which are $\Delta \mathrm{E}, \mu$, $\eta, \omega$ and $\Delta$ Nmax are given at Table 5 at only 6 $311++\mathrm{G}(\mathrm{d}, \mathrm{p})$ basis set in all solvent environments, the other numerical data for the other basis sets combined with all solvents are not given here, they are given supporting information of this text (Table S2). From Table 5, The $\Delta \mathrm{E}$ (energy gap) has increased in the order of $\mathbf{A}(3.4975)<\mathbf{D}(3.9821)<$ C $(4.1378)<\mathbf{E}(4.2678)<$ B (4.2948) < Basic (4.3854) in the water phase. Moreover, this ordering of the energy is found out to be as the same for more than half of the solvent phases at the other basis sets (supplementary material, S3). In according to this result, it can be suggested that the A has the lowest Energy Gap value resulting in the most reactive compound. For the water phase, the $\mu$ has increased in the following order of the $\mathbf{A}$ ($4,0127)<\mathbf{E}(-3,9791)<\mathbf{C}(-3,9767)<\mathbf{B}(-3,9700)<$ D $(-3,8662)$ just like for the DCM, Q, E, M, acetonitrile, and DMSO solvents, but the $\mu$ has increased in as follows: $\mathbf{A}<\mathbf{C}<\mathbf{E}<\mathbf{B}<\mathbf{D}$ for the gas and chloroform, chlorobenzene phases, at 6 $311++\mathrm{G}(\mathrm{d}, \mathrm{p})$ basis set. For the $6-31+\mathrm{G}(\mathrm{d}, \mathrm{p})$ basis set, the $\mu$ has also increased in the order of $\mathbf{A}<\mathbf{C}<$ $\mathbf{E}<\mathbf{B}<\mathbf{D}$ for more than half of the solvent environments. Although there is some changing in the ordering of the $\mu$ depending on the solvent media and on the basis set (for example, the $\mathbf{E}$ and C have replaced with each other in the ordering of the $\mu$ ), the $\mathbf{A}$ is the most stable compound because it has the lowest electronic chemical potential energy.On the other hand, for all basis sets and for the more than half of the solvents, the $\eta$ has increased in the following order of $\mathbf{A}<\mathbf{D}<\mathbf{C}<\mathbf{B}<$ $\mathbf{E}<$ Basic which indicates the structure $\mathbf{A}$ is the soft molecule and therefore it is the most reactive structure among the being studied structures. In according with the electrophilicity index results, it increases as $\mathbf{B}<\mathbf{E}<\mathbf{D}<\mathbf{C}<\mathbf{A}$, in the toluene, chloroform, chlorobenzene, dichloromethane, quinoline and, ethanol media at $6-311++\mathrm{G}(\mathrm{d}, \mathrm{p})$ basis set. The structure $\mathbf{A}$ has been found to be the best electrophile among the all studied structures. The $\Delta$ Nmax changes with the ordering of the $\mathbf{B}<\mathbf{E}$ $<\mathrm{C}<\mathrm{D}<\mathrm{A}$ for more than half of the solvents at all 
basis sets, and the structure $\mathbf{A}$ has the capability of the maximum charge transfer.

Table 5. The calculated quantum chemical parameters with the B3LYP/6-311++G** basis set.

\begin{tabular}{|c|c|c|c|c|c|c|c|c|c|c|c|c|}
\hline Molecule & Solvent & $\Delta \mathrm{E}$ & $\mu$ & $\eta$ & $\omega$ & $\Delta \mathrm{Nmax}$ & Solvent & $\Delta \mathrm{E}$ & $\mu$ & $\eta$ & $\omega$ & $\Delta \mathrm{Nmax}$ \\
\hline Basic & & 4.4374 & -3.9218 & 2.2187 & 3.4662 & 1.7676 & & 4.3906 & -3.9643 & 2.1953 & 3.5794 & 1.8058 \\
\hline $\mathbf{A}$ & $=\overparen{F}$ & 3.4893 & -3.9259 & 1.7447 & 4.4172 & 2.2503 & $=\sqrt{n}$ & 3.4939 & -3.9987 & 1.7470 & 4.5764 & 2.2889 \\
\hline B & चै & 4.2970 & -3.8892 & 2.1485 & 3.5201 & 1.8102 & & 4.2972 & -3.9614 & 2.1486 & 3.6519 & 1.8437 \\
\hline C & 을 & 4.1307 & -3.9059 & 2.0653 & 3.6934 & 1.8912 & & 4.1399 & -3.9688 & 2.0700 & 3.8047 & 1.9173 \\
\hline D & $=\underbrace{\mathscr{E}}$ & 3.9789 & -3.7720 & 1.9894 & 3.5760 & 1.8960 & & 3.9821 & -3.8561 & 1.9911 & 3.7341 & 1.9367 \\
\hline $\mathbf{E}$ & & 4.3927 & -3.9401 & 2.1964 & 3.5341 & 1.7939 & & 4.2744 & -3.9710 & 2.1372 & 3.6891 & 1.8580 \\
\hline Basic & & 4.4161 & -3.9395 & 2.2081 & 3.5144 & 1.7842 & & 4.3887 & -3.9661 & 2.1943 & 3.5842 & 1.8074 \\
\hline $\mathbf{A}$ & & 3.4918 & -3.9544 & 1.7459 & 4.4782 & 2.2650 & $\overline{0}$ & 3.4942 & -4.0021 & 1.7471 & 4.5838 & 2.2907 \\
\hline B & 흉 & 4.3035 & -3.9202 & 2.1517 & 3.5711 & 1.8219 & & 4.2964 & -3.9643 & 2.1482 & 3.6579 & 1.8454 \\
\hline C & & 4.1342 & -3.9319 & 2.0671 & 3.7395 & 1.9021 & & 4.1394 & -3.9715 & 2.0697 & 3.8104 & 1.9189 \\
\hline D & 를 & 3.9772 & -3.8077 & 1.9886 & 3.6454 & 1.9148 & $\sum \underbrace{\| \omega}$ & 3.9821 & -3.8597 & 1.9911 & 3.7410 & 1.9385 \\
\hline $\mathbf{E}$ & & 4.2983 & -3.9301 & 2.1492 & 3.5935 & 1.8287 & & 4.2722 & -3.9737 & 2.1361 & 3.6960 & 1.8603 \\
\hline Basic & & 4.4115 & -3.9437 & 2.2058 & 3.5256 & 1.7879 & & 4.3884 & -3.9665 & 2.1942 & 3.5851 & 1.8077 \\
\hline $\mathbf{A}$ & & 3.4923 & -3.9617 & 1.7462 & 4.4942 & 2.2688 & & 3.4945 & -4.0031 & 1.7472 & 4.5857 & 2.2911 \\
\hline B & & 4.3035 & -3.9276 & 2.1517 & 3.5845 & 1.8253 & & 4.2961 & -3.9652 & 2.1481 & 3.6598 & 1.8460 \\
\hline C & $\stackrel{0}{0}=$ & 4.1359 & -3.9382 & 2.0679 & 3.7499 & 1.9044 & & 4.1391 & -3.9722 & 2.0696 & 3.8120 & 1.9193 \\
\hline D & & 3.9775 & -3.8160 & 1.9887 & 3.6610 & 1.9188 & & 3.9821 & -3.8605 & 1.9911 & 3.7426 & 1.9389 \\
\hline $\mathbf{E}$ & & 4.2945 & -3.9375 & 2.1473 & 3.6102 & 1.8337 & & 4.2716 & -3.9745 & 2.1358 & 3.6980 & 1.8609 \\
\hline Basic & & 4.4025 & -3.9523 & 2.2013 & 3.5481 & 1.7955 & & 4.3870 & -3.9677 & 2.1935 & 3.5884 & 1.8088 \\
\hline $\mathbf{A}$ & 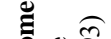 & 3.4931 & -3.9768 & 1.7466 & 4.5275 & 2.2769 & & 3.4945 & -4.0055 & 1.7472 & 4.5913 & 2.2925 \\
\hline B & 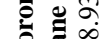 & 4.3016 & -3.9421 & 2.1508 & 3.6127 & 1.8329 & ص્ & 4.2953 & -3.9673 & 2.1477 & 3.6643 & 1.8473 \\
\hline C & 을 & 4.1386 & -3.9510 & 2.0693 & 3.7718 & 1.9093 & $\sum$ 于 & 4.1386 & -3.9741 & 2.0693 & 3.8161 & 1.9205 \\
\hline D & & 3.9799 & -3.8330 & 1.9900 & 3.6915 & 1.9262 & $\theta \underbrace{\| \omega}$ & 3.9821 & -3.8629 & 1.9911 & 3.7473 & 1.9401 \\
\hline $\mathbf{E}$ & & 4.2869 & -3.9519 & 2.1434 & 3.6431 & 1.8437 & & 4.2703 & -3.9765 & 2.1351 & 3.7030 & 1.8624 \\
\hline Basic & & 4.4020 & -3.9529 & 2.2010 & 3.5496 & 1.7959 & & 4.3854 & -3.9693 & 2.1927 & 3.5927 & 1.8103 \\
\hline $\mathbf{A}$ & $\stackrel{\Xi}{\Xi}$ & 3.4931 & -3.9776 & 1.7466 & 4.5293 & 2.2774 & 6 & 3.4975 & -4.0127 & 1.7487 & 4.6039 & 2.2946 \\
\hline B & 흥 & 4.3013 & -3.9428 & 2.1507 & 3.6142 & 1.8333 & $m$ & 4.2948 & -3.9700 & 2.1474 & 3.6698 & 1.8488 \\
\hline C & $\Xi \vec{a}$ & 4.1389 & -3.9516 & 2.0694 & 3.7729 & 1.9095 & $3^{\pi}$ & 4.1378 & -3.9767 & 2.0689 & 3.8219 & 1.9221 \\
\hline D & $\tilde{\sigma} \|$ & 3.9802 & -3.8337 & 1.9901 & 3.6925 & 1.9264 & 这 & 3.9821 & -3.8662 & 1.9911 & 3.7536 & 1.9418 \\
\hline $\mathbf{E}$ & & 4.2866 & -3.9526 & 2.1433 & 3.6446 & 1.8442 & & 4.2678 & -3.9791 & 2.1339 & 3.7099 & 1.8647 \\
\hline
\end{tabular}

\section{CONCLUSION}

In this work, we have investigated the Basic compound and its $\mathrm{C} 1$-substituted derivatives to determine which substituent group makes the chemical reactivity behavior of the Basic compound enhanced more. For this reason, we have conducted the comprehensive quantum chemical analysis including the electronic structure analysis, thermodynamic parameters such as dipole moment and free energy, NBO analysis, FMO analysis and quantum chemical parameters. In conclusion, the compound $\mathbf{A}$ is determined as the most reactive compound because its Energy Gap is the lowest than those of the other compounds. In addition, it is the soft molecule, having the highest electrophilicity index and the capability of maximum charge transfer. It is important to declare that the anthracene-9-yl substitution on the $\mathrm{C} 1$ - position of the Basic compound has increased the chemical reactivity of the Basic compound more than those of the other substituent group. It is supported by the NBO analysis: the highest electron delocalization for the structure $\mathbf{A}$ was found out $\pi \mathrm{C} 19-\mathrm{C} 20 \rightarrow \mathrm{p}_{\mathrm{v}} \mathrm{C} 42-\mathrm{C} 43$ with the interaction energy of the $50.98 \mathrm{kcalmol}^{-1}$ due to the anthracene-9-yl substitution on the C1-position of the Basic structure makes the electron delocalization on the substituted compound enhances, at $6-311++\mathrm{g}^{* *}$ basis set in the water phase. Although it is predicted the $\mathbf{A}$ including the anthracene-9-yl substituent group on it as the most reactive structure among the investigated compounds, it is necessary to keep in mind that there are a lot of the factors affecting the chemical reactivity behavior. Hopefully, the findings of this study containing the comprehensive quantum 
chemical analysis (time-consuming calculations and their analysis) will provide an important information in understanding /be explaining the reactivity behavior of $\beta$-Carboline compounds.

\section{Acknowledgments}

The authors thank to the Department of the Scientific Research Projects, Cumhuriyet University (Project Nos: EĞT-066 and EĞT-053) for the financial support. All calculations have been conducted at TUBITAK ULAKBIM, High Performance and Grid Computing Center (TR-Grid e- Infrastructure).

\section{REFERENCES}

[1] Martin L., Leon A., Martin M. A., Castillo B. and Menendez J.C., "Detection and characterization of cyclodextrin complexes with $\beta$-carboline derivatives by spectroscopic techniques", Journal of Pharmaceutical and Biomedical Analysis, 2003, 32, 991-1001.

[2] Pari K., Sundari C. S, Chandani S., Balasubramanian D., " $\beta$-Carbolines That Accumulate in Human Tissues May Serve a Protective Role against Oxidative Stress", THE JOURNAL OF BIOLOGICAL CHEMISTRY. 2000, 275(4), 2455-2462.

[3] Prinsep M. R, Blunt J.W. and Munro M.H.G, "New Cytotoxic $\beta$-Carboline Alkaloids from the Marine Bryozoan, Cribricellina Cribraria", Journal of Natural Products. 1991, 54(4), 1068-1076.

[4] Allen M.S., Tan Y.C., Trudell M.L., Narayanan K., Schindler L.R., Martin M.J., Schultz C., Hagen T.J., Koehler K.F., Codding P.W., Skolnick P. and Cook J.M., "Synthetic and Computer-Assisted Analyses of the Pharmacophore for the Benzodiazepine Receptor Inverse Agonist Site", J. Med. Chem., 1990, 33: 2343-2357.

[5] Allen M.S., LaLoggia A.J., Dorn L.J., Martin M.J., Costantino G., Hagen T.J., Koehler K.F., Skolnick P. and Cook J.M., "Predictive Binding of $\beta$-Carboline Inverse Agonists and Antagonists via the CoMFA/GOLPE Approach" J. Med. Chem., 1992, 35: 40014010.
[6] Glennon R.A., Dukat M., Grella B., Seo Hong S.S., Costantino L., Teitler M., Smith C., Egan C., Davis K. and Mattson M.V., "Binding of $\beta$ -carbolines and related agents at serotonin (5HT2 and 5-HT1A), dopamine (D2) and benzodiazepine receptors", Drug and Alcohol Dependence, 2000, 60: 121-132.

[7] Brahmbhatt K.G., Ahmed N., Sabde S., Mitra D., Singh I.P. and Bhutani K.K., "Synthesis and evaluation of $\beta$-carboline derivatives as inhibitors of human immunodeficiency virus", Bioorganic \& Medicinal Chemistry Letters, 2010, 20: 4416- 4419.

[8] Kusurkar R.S and Goswami S.K., "Efficient one-pot synthesis of anti-HIV and anti-tumour $\beta$-carbolines", Tetrahedron, 2004, 60: 53155318.

[9] Bai B., Li X.Y., Liu L., Li Y and Zhu H.J., "Syntheses of novel $\beta$-carboline derivatives and the activities against five tumor-cell lines", Bioorganic \& Medicinal Chemistry Letters, 2014, 24: 96- 98.

[10] Cao R., Fan W., Guo L., Ma Q., Zhang G., Li J., Chen X., Ren Z. and Qiu L., "Synthesis and structure-activity relationships of harmine derivatives as potential antitumor agents", European Journal of Medicinal Chemistry, 2013, 60: 135-143.

[11] Cao R., Peng W., Chen H., Hou X., Guan H., Chen Q., Ma Y. and Xu A., "Synthesis and in vitro cytotoxic evaluation of 1,3-bisubstituted and $\quad 1,3,9$-trisubstituted $\quad \beta$-carboline derivatives", European Journal of Medicinal Chemistry, 2005, 40: 249-257.

[12] Bai B., Li X.Y., Liu L., Li Y. and Zhu H.J., "Design, synthesis and cytotoxic activities of novel $\beta$-amino alcohol derivatives", Bioorganic \& Medicinal Chemistry Letters, 2011, 21: 2302-2304.

[13] Chen Z., Cao R., Shi B., Guo L., Sun J., Ma Q., Fan W. and Song H., "Synthesis and biological evaluation of 1,9-disubstituted $\beta$ carbolines as potent DNA intercalating and cytotoxic agents", European Journal of Medicinal Chemistry, 2011, 46: 5127-5137.

[14] Reyman D., Tapia M.J., Carcedob C. and Vinasc M.H., "Photophysical properties of methyl $\beta$-carboline-3-carboxylate mediated 
by hydrogen-bonded complexes-a comparative study in different solvents", Biophysical Chemistry, 2003, 104: 683-696.

[15] Carmona C., Balon M., Coronilla A.S. and Munoz M.A., "New Insights on the ExcitedState Proton-Transfer Reactions of Betacarbolines: Cationic Exciplex Formation", J. Phys. Chem. A., 2004, 108: 1910-1918.

[16] Tarzi O.I. and Erra-Balsells R., "Photochemistry of the alkaloids eudistomin $\mathrm{N}$ (6-bromo-nor-harmane) and eudistomin $\mathrm{O}$ (8-bromo-nor-harmane) and other bromo- $\beta$ carbolines", Journal of Photochemistry and Photobiology B: Biology, 2005, 80: 29-45.

[17] Tarzi O.I. and Erra-Balsells R., "Effect of chlorine as substituent on the photochemistry and acid-base properties of $\beta$-carboline alkaloids", Journal of Photochemistry and Photobiology B: Biology, 2006, 82: 79-93.

[18] Reyman D., Pardo A. and Poyato J.M.L., "Phototautomerism of $\beta$-Carboline", J. Phys. Chem., 1994, 98: 10408-10411.

[19] Biondic M.C. and Erra-Balsells R., "Photochemical behaviour of $\beta$-carbolines. Part 4. Acid-base equilibria in the ground and excited states in organic media", J. Chem. Soc. Perkin Trans., 1997, 2:1323-1327.

[20] Guan H., Liu X., Peng W., Cao R., Ma Y., Chen H. and Xu A., " $\beta$-Carboline derivatives: Novel photosensitizers that intercalate into DNA to cause direct DNA damage in photodynamic therapy", Biochemical and Biophysical Research Communications, 2006, 342: 894-901.

[21] Ponce M.A. and Erra-Balsells R., "Synthesis and Isolation of Nitro- $\beta$-carbolines Obtained by Nitration of Commercial $\beta$-Carboline Alkaloids", J. Heterocyclic Chem., 2001, 38, 1071-1082.

[22] Tapia M.J., Reyman D., Viñas M.H., Arroyo A. and Poyato J.M.L., "An experimental and theoretical approach to the acid-base and photophysical properties of 3 -substituted $\beta$ carbolines in aqueous solutions", Journal of Photochemistry and Photobiology A: Chemistry, 2003, 156: 1-7.
[23] Frisch M.J. et. al, Gaussian 09, D.01. Gaussian, Inc, 2013, Wallingford CT.

[24] Becke A.D., "A new mixing of Hartree-Fock and local density-functional theories" J. Chem. Phys., 1993, 98: 1372- 1377.

[25] Lee C., Yang W. and Parr R.G., "Development of the Colle-Salvetti correlation-energy formula into a functional of the electron density", Phys. Rev., 1988, B37: 785- 789 .

[26] Foresman J.B., Keith T.A., Wiberg K.B., Snoonian J. and Frisch M.J., "Solvent Effects. 5. Influence of Cavity Shape, Truncation of Electrostatics, and Electron Correlation on ab Initio Reaction Field Calculations", J. Phys. Chem., 1996, 100: 16098- 16104.

[27] Tomasi J., Mennuci B. and Cammi R., "Quantum Mechanical Continuum Solvation Models", Chem Rev., 2005, 105: 2999- 3093.

[28] Fukui K., "Role of frontier orbitals in chemical reactions", Science, 1982, 218(4574): 747- 754.

[29] Jensen F., "Introduction to Computational Chemistry", John Wiley and Sons Ltd., West Sussex, Chapter 9, p. 309, p. 492, 2007.

[30] Parr R.G, Szentpaly L.V. and Liu S. "Electrophilicity Index", J. Am. Chem. Soc., 1999, 121: 1922-1924.

[31] Codding P.W., "Structure-activity studies of $\beta$ -carbolines. 1. Molecular structure and conformation of cis-3-carboxylic acidP,2,3,4-tetrahydroharmane dihydrate", Can. J. Chem., 1983, 61: 529-532.

[32] Dorey G., Poissonnet G., Potier M.C., Carvalho L.P., Venault P., Chapouthier G., Rossier J., Potier P. and Dodd R.H. "Synthesis and Benzodiazepine Receptor Affinities of Rigid Analogues of 3-Carboxy- $\beta$-carbolines: Demonstration That the Benzodiazepine Receptor Recognizes Preferentially the s-Cis Conformation of the 3-Carboxy Group" J. Med. Chem., 1989, 32: 1799-1804.

[33] Wiberg K.B., "Properties of Some Condensed Aromatic Systems", J. Org. Chem., 1997, 62: 5720-5727.

[34] Weinhold F., Landis C.R. and Glendening E.D., "What is NBO analysis and how is it 
useful?", International Reviews in Physical Chemistry, 2016, 35(3): 399-440.

[35] Reed A.E., Curtiss L.A., Weinhold F., "Intermolecular Interactions from a Natural Bond Orbital, Donor-Acceptor Viewpoint", Chem. Rev., 1988, 88: 899-926.

[36] Cramer, C. J., "Essentials of the Computational Chemistry: Theories and Models", Second edition, John Wiley and Sons Ltd., West Sussex, Chapter 6, p.578.

[37] Suresh D.M., Amalanathan M., Sebastian S., Sajan D., Joe I.H., Jothy V.B. and Nemec I., "Vibrational spectral investigation and natural bond orbital analysis of pharmaceutical compound 7-Amino-2,4dimethylquinolinium formate- DFT approach", Spectrochimica Acta Part A: Molecular and Biomolecular Spectroscopy, 2013, 115: 595-602.

[38] Zhang, J., Zheng, H., Zhang, T. and Wu, M., "Theoretical Study for High-Energy-Density Compounds Derived from Cyclophosphazene. IV. DFT Studies on 1,1Diamino-3,3,5,5,7,7-

hexaazidocyclotetraphosphazene and Its Isomers", Int. J. Mol. Sci., 2009, 10: 35023516.

[39] Sayın, K. , Karakaş, D., "Theoretical studies on oxovanadium(IV) complexes with sterically crowded Schiff base ligands", Cumhuriyet Science Journal, 2017, 38 (1), 112. 